\title{
Unicorns—what drives multibillion-dollar valuations?
}

\author{
Carolin Bock $^{1} \cdot$ Christian Hackober ${ }^{1}$
}

Received: 16 October 2019/Accepted: 9 July 2020/Published online: 29 July 2020

(C) The Author(s) 2020

\begin{abstract}
The number of ventures with a market value of one billion USD or more has considerably increased during the last decade. Driven by new technologies and business models, these ventures became an integral part of our daily life. Particularly, the number of unicorns based in China and other regions outside the US raised during recent years whereas the phenomenon was initially limited to the US region. Existing research has mainly focused on descriptive approaches to examine the rise of these ventures but lacks knowledge on the drivers of this phenomenon. We address these research gaps and investigate the underlying factors that foster the emergence of such high-valued ventures. Our results present several economic environmental as well as investor-related factors that impact the likelihood for a venture to achieve a market valuation of more than one billion USD. Subsequently, we derive theoretical and practical implications that may foster the future emergence of new high-valued ventures, covering regulatory, investor- and venturespecific aspects.
\end{abstract}

Keywords Venture valuation - Venture capital · Corporate venture capital · Disruption · Unicorn · Private companies

Christian Hackober

hackober@ent.tu-darmstadt.de

Carolin Bock

bock@ent.tu-darmstadt.de

1 Institute of Entrepreneurship, Technische Universität Darmstadt, Hochschulstr. 1, 64289

Darmstadt, Germany 


\section{Introduction}

During the last decade a comparably new development began to evolve in the field of venture capital (VC) with the increasing occurrence of so called "unicorns". Originally introduced by Aileen Lee (Brown and Wiles 2015) the term "unicorns" describes companies that have always been private, have received at least one funding round of institutional capital, are not a divisional buyout of a public company and have an estimated market value of one billion USD or more (Brown and Wiles 2015). In fact, it could be observed that an increasing number of ventures refuse to go public but remain privately owned instead. In order to cover their capital requirements, extended sources of private financing are necessary. So in contrast to previous periods, the median amount of total capital raised by unicorn firms in private financing rounds exceeds the median of technology based IPOs in the meantime (Brown and Wiles 2015). That is why several studies refer to these financing events as "private IPOs" (Kensinger et al. 2000; Milanesi 2012; Brown and Wiles 2015). Although the public and media interest in this particular subgroup of VC backed companies increased since the 2010s, academic research on this topic remained rather limited.

To a certain extent, this lack of studies might be given due to the general scarceness of data in the area of VC (Kaplan and Lerner 2016) which also persists in the case of unicorns. Especially as some studies see the possibility to retain sensitive financial and operational data private for a prolonged time period as an advantage of private ownership (Fenwick and Vermeulen 2015) compared to IPOs and related disclosure procedures. Furthermore, unicorns are still quite rare compared to the remaining universe of ventures. However, the lack of research is quite striking as today's unicorns are expected to disrupt large industry sectors (Divan 2016) which will bring major changes to everybody's daily life. Due to this, politics and governmental institutions recognized the importance of this disruptive potential and started to examine the evolution and location behavior of unicorns (Simon 2016). However, as the current research on unicorns is still rather nascent, one needs to focus on the more general literature and research that discusses high valuation levels in the area of VC. This is in particular the case as existing research that examines unicorns specifically is mainly limited to descriptive studies which report the rise of this phenomenon but do not identify factors that drive the probability for ventures to achieve multibillion USD valuations.

Previous research has identified that a startup's valuation is based on numerous factors including factors that can be observed (e.g. industry, VC investor's quality) as well as on factors that are not publicly known (e.g. company's sales and assets) (Gompers et al. 2006). Due to the better availability of data and more meaningful results, existing research was conducted mainly considering observable factors. For example, Nahata (2008), Ebbers and Wijnberg (2012), Phalippou (2010) and Cumming and Dai (2011) found that the characteristics of investors and their respective quality have a strong impact on the valuation levels of portfolio companies, whereas other studies see the degree of innovation of companies as dominant factor for ventures to become successful (Da Rin et al. 2011). 
Furthermore, Miloud et al. (2012) find sales growth to be a decisive criterion when assessing high valuation levels especially in the high technology industry. Interestingly, Bergemann et al. (2008) show that high valuations in the venture's starting days do not necessarily lead to high valuation levels in later funding rounds which gives some indication that stakeholders along the venture's lifecycle have a material influence on the success probability and ultimately on the valuation levels. In contrast to this finding, Rungi et al. (2016) find that the valuation for ventures, which exceeds the ten billion USD threshold in later funding rounds, is already significantly higher in the second funding round which points to the special nature of unicorns.

However, given the extremely high valuation levels and the meteoric rise of unicorns as well as their unique and strong impact on all stakeholders, we presume that unicorns do not follow entirely common valuation patterns as they remain a very special phenomenon. Taking this into consideration, we conclude that the valuation and success factors of unicorns differ from factors that influence typical and common ventures, making unicorns a very special phenomenon which requires research on the question which factors drive the likelihood of becoming a unicorn.

In order to establish a better understanding of unicorns and their valuation levels, we shed light on the question what drives the probability for young ventures to become a unicorn by identifying differentiating characteristics of ventures. Further, we answer in a second analysis the question what factors are decisive that some unicorns outperform "common" valuation levels. By providing answers to these questions, the contribution of our work is twofold. First, we contribute to the growing literature regarding the growth and emergence of ventures and more specifically on determinants for venture valuation (Lerner 2010; Grilli and Murtinu 2014; Mason and Brown 2014). Second, we provide novel insights how investors' characteristics and economic conditions impact the likelihood for ventures to become a unicorn and hence identify critical influences for venture success. Thereby, our findings can be generalized to a certain extent and transferred to the more general question which conditions influence the success probability of young ventures and how they can be supported on their growth path. Further, our results are relevant to the valuation literature, as we confirm the hypothesis that the growth strategy has an impact on valuation levels (Salamzadeh and Hiroko 2015; Gompers et al. 2016; Meglio et al. 2017) but show simultaneously that other factors might be overestimated in prior research.

\section{Theoretical considerations and hypotheses development}

Reviewing the list of unicorns, the often-cited concentration of unicorns in certain geographical areas becomes obvious. More than three-quarter of the current unicorns are based in the US and China. The number of China-based unicorns increased continuously since 2014 , whereas the number of unicorns founded in the US remains rather stable (Fig. 1).

Further, by reviewing US- and China-based unicorns in detail, a clear domination of certain local areas becomes obvious. Whereas in the US a clear domination of the 


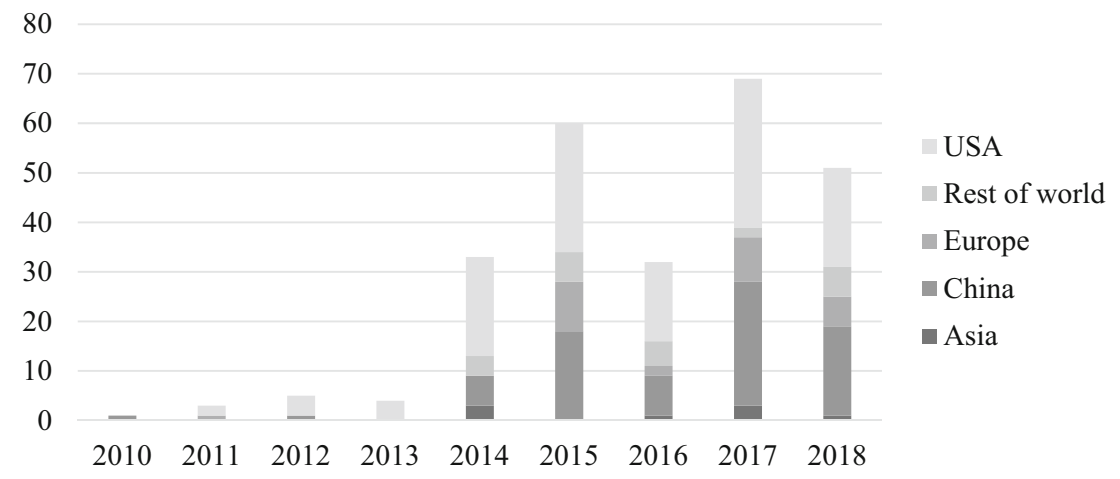

Fig. 1 Number of "unicorn births"

Silicon Valley, followed by the New York area is observable, most unicorns are based in Beijing and Shanghai in China.

However, the speed of the rise of unicorns seems to decrease after reaching its peak in 2017. Figure 1 shows the slowdown as the number of ventures which became a unicorn in 2018 was $26 \%$ below that of 2017 .

The majority of all unicorns operate in the consumer and technology sector followed by unicorns that are active in the field of financial services (Fig. 2). Similar to the origin of unicorns, the majority of unicorns' initial lead investors are based in the US, however, we see an increase of investors based outside the US over time.

Although, we find an increasing public awareness for unicorns, this special form of VC-backed companies has received only limited attention in the current academic discussion so far. Therefore, it seems reasonable to review the more general literature on $\mathrm{VC}$ and startup valuation first and subsequently to deduce relevant aspects for unicorns. By doing this, we identify three potential general areas of influence that might impact the success as well as the valuation of ventures and which can serve as a basis for deducting hypotheses.

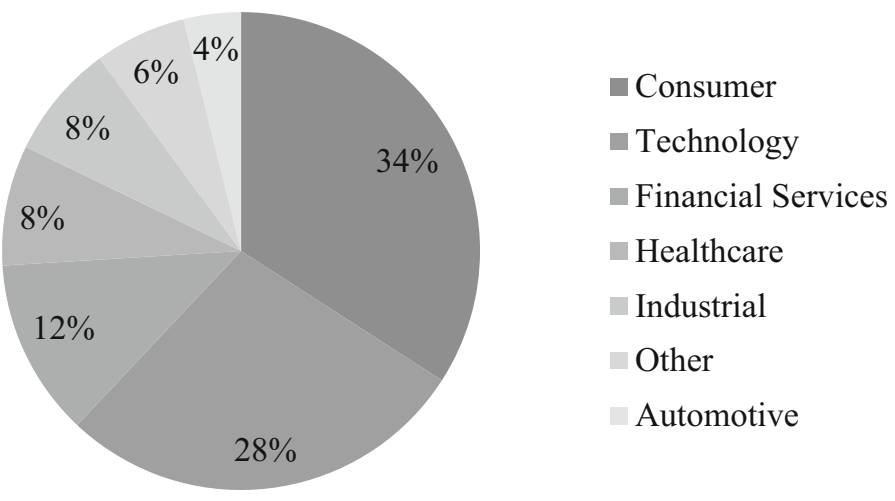

Fig. 2 Industry distribution of unicorns in 2018 
First, we find investor-related factors in existing literature as an influencing category for the success probability of ventures. Experience and investor's skills have a direct influence on the performance of a VC-backed company (Gompers et al. 2006; Bottazzi et al. 2008; Bengtsson and Wang 2010; Achleitner et al. 2013). Especially in the case of venture financing, this aspect seems to be important as VC investors provide usually additional advice in comparison to pure financial backing (Bonini et al. 2012; Jackson et al. 2012).

Second, we identify economic and environmental factors as influencing category for the success probability of ventures in existing research. Innovation clusters represent a special type of economic environment. Further, past research has identified a relationship between overall economic conditions and valuation levels of ventures (e.g. GDP growth, interest rates, number of IPOs) (Romain et al. 2004; Dias and Macedo 2016). This factor is relevant as funds increase the implied valuation of their investments in times of higher capital inflows (Gompers and Lerner 2000).

Last, company-intrinsic factors, i.e. the quality of the venture and its management team, seem to play a role for the success probability (Maschke and Knyphausen-Aufseß 2012). Although it is quite difficult to measure the quality of a venture, the innovativeness seems to have a positive influence on the potential success of a venture (Häussler et al. 2008; Block et al. 2015).

\subsection{Hypotheses development}

Based on the review of existing literature, we develop four hypotheses which we consider as most relevant when assessing whether ventures will achieve a unicorn status and the level of their respective valuation.

\subsubsection{Investor reputation}

A firm's reputation can be described as an intangible asset that is based on public recognition of the quality of a firm's activities and outputs (Shapiro 1983; Rindova et al. 2005; Lee et al. 2011). In particular, reputation, which results from a VC firm's prior experience and performance, is economically important (Achleitner et al. 2018) as it can generate future rents by reducing information asymmetries among different actors (Hsu 2004). In the case of ventures and their respective investors that means that entrepreneurs are able to select superior investors based on their reputation although they did not previously interact with them. For investors, the reputation construct comprises their experience, their network capabilities and the level of direct assistance which they provide to portfolio firms (Hsu 2004). Thereby, highly reputed investors can generate superior performance through two general levers (Haagen 2008; Tykvová 2018). First, it is presumed that they invest in superior ventures (selection effect) and second, their strong operational support for their portfolio companies [e.g. mentoring, financial assistance (MacMillan et al. 1989)] facilitates the successful development of the venture (treatment effect). Given the current levels of capital inflow and the availability of financial capital, reputation gains increasing institutional and investors' awareness for certain venture 
capitalists as financial capital per se is not a differentiating factor among the VC investor universe (Hsu 2004). As a consequence, investors that possess a higher reputation create a higher visibility for themselves (Megginson and Weiss 1991; Krishnan et al. 2011) and attract ventures of superior quality which in turn have a higher probability to achieve a unicorn status.

Furthermore, investors and especially VC firms with high reputation attract fund managers and decision makers with high qualification (Cumming and Dai 2011). Given that, VC firms with higher qualified employees can make better investment decisions and hence invest with a higher likelihood in later unicorns. In addition, more reputable VC firms tend to operate a larger network within their industry (Alexy et al. 2012), which enables them to obtain an information advantage with regard to lucrative investment opportunities. On the other hand, a high reputation together with a proven track record increases the likelihood for a VC firm to receive higher investments (Groh and Liechtenstein 2011). This aspect is relevant as high capital inflows are the basis for the ability to invest in ventures on their unicorn track in consecutive investment rounds, especially to avoid a potential dilution of earlier acquired stakes. Interestingly, Hsu (2004) found that entrepreneurs are even willing to accept a discount on the valuation of their ventures in the first funding rounds in order to access the capital of investors with a high reputation which might be beneficial in the long run. Bygraves and Timmons (1992, p. 208) state "It is far more important whose money you get than how much you get or how much you pay for it".

Nonetheless, beside the superior investment selection made by more reputable investors, which should increase the probability for those ventures to become a unicorn, those VC investors also provide support and advice during their investment period and thus influence ventures' operations directly by interacting with management teams (Alperovych and Hübner 2011). In addition, close relationships between investors and their portfolio companies enable investors to establish a better monitoring which conclusively increases success probabilities of their ventures (Bernstein et al. 2016). Furthermore, investors' support includes business referrals, extensive mentoring, and financial assistance (MacMillan et al. 1989; Breuer and Pinkwart 2018) as well as recruiting executive managers (Hellmann and Puri 2002).

In particular, business referrals should help ventures to increase their speed of growth, especially if these referrals are based on the investor's network. Lindsey (2002) provides empirical evidence for the so called "keiretsu" phenomenon which describes that investors and in particular VC investors act as information brokers in imperfect information markets between different ventures, customers and future investors. More reputable investors have a larger number of portfolio companies making it easier for them to broker strategically important information among them (Hsu 2004). Hence, more reputable investors facilitate the establishment of collaborations between ventures and provide easier market access for them by giving referrals to other market participants. Thus, Lee et al. (2011) conclude that the longer the involvement of reputable investors lasts, the more likely they will add substantive value to the respective ventures. 
Finally, a reputable investor group bears also a signaling effect for other investors in subsequent funding rounds. Future investors are more open to commit higher amounts of capital if they find highly-reputable existing investors among the venture's group of investors. The reputation thereby takes on the role of a certification of the venture (Megginson and Weiss 1991). Of course, this effect leads to a rather increasing valuation and therefore increases the probability for ventures to achieve a unicorn status.

Taking these aspects into consideration, we derive the following hypothesis:

Hypothesis 1 A high investor reputation increases a venture's probability to achieve unicorn status.

\subsubsection{Economic clusters}

Past research has identified several factors that foster the establishment of new ventures in certain geographical areas, leading to clusters of innovation. Originally, three players were identified that facilitate the creation of clusters: universities and research institutions, large companies and the government (Leydesdorff and Etzkowitz 1996). However, recent research demonstrates that the establishment of clusters is way more complex and applies complex network theory to shed some light on the operating principles of innovation clusters (Ferrary and Granovetter 2009). Generally, clusters provide unique conditions for new ventures and consist of a network of companies that are geographically concentrated (Khan and Ghani 2004) which can be described as an ecosystem that promotes the creation of companies and enhances competitiveness (Lemarié et al. 2001; Carlsson 2002; Yamawaki 2002; Sternberg and Litzenberger 2004). Clusters show higher growth rates than other regions and past research found that the performance of young firms benefits from being founded within such clusters (Gilbert et al. 2008; Delgado et al. 2010). Subsequently, we assume that being founded within one of these ecosystems influences also the occurrence of unicorns.

First of all, the availability of human capital is thereby a differentiating factor. In particular, the availability of highly educated people seems to be essential for the establishment of innovative venture firms. Hence, Calcagnini et al. (2016) showed that the distance to universities is positively correlated with the creation of innovative ventures. Beside of the availability of human capital, they identified also other spillover mechanisms like patents, collaboration agreements and university spin-offs as favorable for the establishment of new ventures (Ubeda et al. 2019). Further, being founded within a cluster provides new ventures the opportunity to access marketplaces early, as potential customers of new innovative products are also part of the cluster, and give faster feedback on the functionality of the products (Gilbert et al. 2008). As a result, cluster participants should be able to adapt their products faster to customer needs and ultimately offer superior services or products. This goes in line with the argument that clusters force new ventures to be more competitive as competition is higher in these regions (Gilbert et al. 2008) but facilitates also differentiation behavior as entrepreneurs can recognize gaps in 
existing products or services and fill them by providing new products or services (Gilbert et al. 2008).

In addition to these rather venture-specific influences, clusters offer usually better financing conditions for new ventures based on the high availability of private capital in these regions. In fact, technology and innovation clusters typically show a high density of $\mathrm{VC}$ investors which provide the required funding for new ventures on their growth paths (Castilla 2003). Clusters facilitate the access to this funding and hence increase the speed of development of the respective ventures (Inderst and Müller 2004; Gaba and Meyer 2008).

In the US, past research has predominantly identified three relevant clusters when examining influencing factors and ecosystems for innovative ventures. First of all, the Silicon Valley serves as quasi role model for an innovation and technology cluster which is at the same time the origin of some of the most renowned and reputable VC investors (Saxenian 1994; Feldman 2001). Rosenthal and Strange (2003, p. 377) assume Silicon Valley to be "one of the most productive economies on the planet" in the area of software and computer-related industries. Further, the greater Boston area (Route 128) has been identified as a successful case for an innovation ecosystem in the biopharma area by Panetti et al. (2019) and was also included in the research of others (Feldman 2001).

However, beside Silicon Valley and Route 128, New York is the third area that has been identified as a regional area that produces a considerable number of new ventures majorly in the fintech area due to its strong financial sector (Romanelli and Khessina 2005; Zhang 2009).

Though, during the last years, new clusters evolved predominantly in China. Accompanied by the general economic rise, the Beijing area as well as the Shanghai area became clusters for the foundation of new innovative ventures including the provision of university and knowledge infrastructure as well as sources of funding (Zhou and Xin 2003; Long and Zhang 2011). Both regions are among the most innovative provinces in China (Wang et al. 2015). Although, these clusters are younger than established ones like the Silicon Valley, we assume that the venture development within these clusters follows basically the same patterns. In particular, we assume that unicorns, as unquestionable the most successful representatives of VC-backed companies, benefit from the conditions within clusters. Hence, we derive the following hypothesis:

Hypothesis 2 Ventures that are founded within a technological innovation cluster possess a higher likelihood to become a unicorn.

\subsubsection{Corporate venture capital}

During the last years, a couple of new investor types for financing new business ventures entered the market (Block et al. 2018). In particular, the activity level of corporate venture capital (CVC) investors rebound after it had collapsed following the bursting of the dotcom bubble. However, objectives and investment conditions set by CVC investors are different from independent venture capital investors. Goals and objectives for CVCs can be generalized only to a certain degree due to the fact 
that $\mathrm{CVC}$ programs are as unique as their parent corporations, although, they have one thing in common. Instead of being just a financial activity, CVC investors can be regarded as a combination of strategic and financial operations (Block et al. 2018; Rossi et al. 2017).

In most cases, CVCs try to obtain access to new technologies, markets and high qualified employees when investing in ventures. Usually these attempts include to leverage innovations of the venture (Galloway et al. 2017). This might be beneficial for the ventures as CVCs offer access to non-financial assets of the parent corporation. These services include expertise and infrastructure for product development, manufacturing, legal, sales, distribution and customer service activities among others (Park and Steensma 2012). Offering this non-financial support may facilitate the development of the venture and help to avoid failures compared to ventures backed by independent investors only, as they often lack relevant industry experience. Following this argument, Rossi et al. (2017) found that corporate investors engage with ventures in a more meaningful way by connecting them with the broader entrepreneurial ecosystem.

Indeed, providing ventures with support to access complementary assets differentiates corporate investors from pure financial investors and can help ventures to commercialize their products or services (Paik and Woo 2017; Röhm et al. 2018). In particular, there seems to be certain evidence that the level of innovativeness and the research intensity increases when corporate investors grant access to those complementary assets (Alvarez-Garrido and Dushnitsky 2016) which is in line with Kelly and Kim (2018) who find a positive relationship between general VC-backing and the growth in R\&D expenditures and Park and Steensma (2013) who find that rates of innovation enhance in particular for ventures funded by corporate investors.

As we consider unicorns as highly innovative, the more general findings regarding the innovativeness and corporate-backing are transferable without any limitations to unicorns as a special subset of ventures. Furthermore, established corporate investors can reduce the widespread uncertainty for new technologies that are introduced by innovative ventures. By backing these ventures, incumbents generate a technology endorsement effect as they signal markets that they are convinced by a technology which is a strong argument for other market participants to apply these products (Paik and Woo 2017). Thus, receiving funding from a CVC investor can be regarded as a certification for the venture's products or services. As many unicorns have developed disruptive and innovative products and services, we assume that the technology endorsement effect should hold especially for this subgroup of ventures. In particular, the endorsement as well as the certification effect is supposed to have a positive influence on the development of ventures by lowering market entry barriers for them and enabling stronger sales growth.

Further, Chesbrough (2002) found that CVC investors are more patient when it comes to returns and exits. In fact, corporate investors have less time constraints in their investment horizon (Paik and Woo 2017) which enables ventures and subsequently later unicorns to spend more time to develop products and services which could lead to a superior quality of the latter which should also be beneficial for the development of unicorns. Furthermore, more patient CVC investors are 
willing to remain invested for a longer time than independent $\mathrm{VC}$ funds with a finite lifetime and hence enable high follow-on funding rounds instead of promoting an exit through an IPO which gives unicorns the possibility to grow (Wadhwa and Phelps 2009; Guo et al. 2015).

Past research has found some evidence that CVC can outperform independent $\mathrm{VC}$ investors at least if there is a strategic fit between the venture and the investor (Morck 2000). Taking the different influences and effects into consideration we derive the following hypothesis:

Hypothesis 3 CVC-backing increases a venture's probability to achieve unicorn status.

\subsubsection{Growth strategy}

In general, it is difficult to answer why, e.g. Airbnb, achieves a post-money valuation of $\$ 30 \mathrm{bn}$ without having any relevant assets and even more interesting for what they spend almost $\$ 4$ bn of funding without having a research-intensive or high-tech business model (Filloux 2014). But having a closer look at unicorns and prospective candidates, it becomes obvious that a lot of their valuation is based on market shares and strong growth rates.

One of the reasons for this development is that investors often accept growth metrics as proxies for value and hence are primarily interested in increasing users, engagement, customer acquisition, retention rates and revenues. Thereby, investors are comfortable to absorb high losses if they see a chance to lock-in "a position to generate quasi-monopolistic profits and, by extension, enormous capital gains" (Kenney and Zysman 2019, p. 46).

A second reason for this strong focus on growth is that unicorns and their respective investors aim for a market-dominating position especially when operating a platform business model and thus try to drive incumbents and other new entrants out of their market by acquiring them (Kenney and Zysman 2019). VC investor Solomon (2015) reasons also that most of the valuation is about market shares and the ability to overwhelm competitors which is in line with the findings of Kaplan and Strömberg (2000) who find that it is decisive in investment decisions for investors that ventures offer high growth potentials in particular through acquisitions.

As a result, unicorns become often-as Ramadan et al. (2014) call them"category king" as they define, develop and dominate new markets.

However, in order to gain market shares rapidly in a highly competitive environment with low market entry barriers, unicorns and prospective candidates are forced to make add-on acquisitions. This is in line with Stayton and Mangematin (2018, p. 28) who find "to be first to market in winner-takes-all-market niches" as key success factor for the creation of new ventures. The general application of "buy and build" or "inorganic growth" strategies in order to generate value is thereby already well known from the private equity domain (Hammer et al. 2017), however, in a less aggressive manner. In practice, the aggressive inorganic growth strategy can be observed for example in the case of Snapdeal, an Indian e-commerce 
company, which acquired 7 companies in 7 months in 2015 backed up by previous big ticket investments (Tiwari et al. 2019).

Thereby, inorganic growth strategies cannot only be beneficial from a market share and sales perspective but also from a cost perspective. Add-on acquisitions offer the opportunity for the acquirer to leverage synergies and hence to drive the value of the combined businesses (Das and Kapil 2015; Hammer et al. 2016). Furthermore, inorganic growth allows the acquirer to access technologies (Zou et al. 2010) and assets which are possessed by the acquisition target and which can be used more efficiently or reallocated following the transaction (Borell and Heger 2013). Subsequently, a higher asset utilization rate or more favorable asset allocation generates certain value for the combined firm. Lastly, the conduction of add-on acquisitions enables the respective venture to overcome the "liabilities of smallness" faster as larger firms have easier access to capital and labor and are less vulnerable to external shocks, which is reflected in a valuation premium and favored by investors (Hammer et al. 2016).

While following aggressive growth strategies, this strategy enables some kind of self-enforcing development as ventures need capital to execute add-on acquisitions and become more likely funded due to their higher market share at the same time. At first glance, that seems to be a chicken or egg dilemma which it is not in fact as the venture or potential unicorn needs an initial funding to dispose of the capital needed for add-on acquisitions (Hammer et al. 2017). Rather, it seems reasonable to presume that investors are able to identify promising startups and support them on a rather aggressive strategy to gain market share (Kaplan and Strömberg 2000). This development is in line with Hammer et al. (2017) who presume that inorganic growth strategies are deterministic and planned components of the investment case rather than the result of opportunistic behavior during the holding period.

Though, ventures are required to achieve a "critical" size from a funding perspective in order to have sufficient financial resources and the capabilities to execute acquisitions. Hence, although inorganic growth strategies and potentials related to it might already exist in the very beginning of a venture, they become only obvious when being executed in a later funding round of a venture.

This leads to the following hypothesis:

Hypothesis 4 Inorganic growth is driving post-money valuation of unicorns.

\section{Data}

As our research addresses two different questions, we perform two independent analyses with different data samples. First, we conduct a hierarchical logistic regression analysis in order to examine which factors are driving the likelihood for ventures to achieve a unicorn status, i.e. a post-money valuation of more than one billion USD. Second, we conduct a linear regression in order to assess our hypothesis that the post-money valuation of unicorns is primarily driven by their inorganic growth strategy. For both types of analysis, we construct a unique dataset as described in the following. 


\subsection{Dataset}

Our sample comprises 258 venture-backed companies valued with one billion USD or more based on their post-money valuation. The list and post-money valuation of identified companies was retrieved from CB Insights global unicorn club list as per Nov 4th 2018 (CB Insights 2018). Due to missing data, we needed to reduce our sample size to 215 individual unicorns in our analysis. In particular, we face missing founding dates as well as latest funding dates which are required to control for the economic environment during this time and to construct our peer group. Furthermore, for ten unicorns, the initial investor was not disclosed and hence the assessment of reputation not possible.

To answer the question which factors drive the probability for ventures to become a unicorn, we make use of a peer group comparison. Subsequently, we have identified a direct peer for 113 unicorns which results in a total dataset of 226 companies (113 unicorns and 113 peers i.e. non-unicorns). For the exact matching procedure, we applied a similar procedure as Puri and Zartuskie (2012) as exact matching is the simplest and the most robust way to match two observations (Kelly and Kim 2018). Exact matching thereby describes a procedure which identifies peers based on the same numerical figures for given covariates. Usually that results in robust results but can be highly data-intensive for large datasets (Kelly and Kim 2018). Thus, the selection process conducted three steps in order to ensure a high similarity between unicorns and their peers and to limit external influences. First, we assumed for all peers that they are based in the same country. Second, we take only peers that are operating in the same industry as the unicorns based on the Crunchbase data and last, we request for peers that the founding dates are within a period of time of less than 12 months. Further, we needed to reduce the sample size for our second analysis (linear regression) from 258 unicorns to 235 due to missing data.

Remaining data on company and funding round details is also derived from Crunchbase, a free online database which was founded in 2005 and which provides information about technology companies, investors, and funding details majorly focused on the US market.

Though the Crunchbase database is comparably young, it becomes increasingly popular in VC research (Werth and Boeert 2013; Homburg et al. 2014; Croce et al. 2016; Schlichte et al. 2019). Further, the coverage of Crunchbase is on a comparable level to other more established data sources like Thomson One Private Equity (Werth and Boeert 2013) or data recorded by the National Venture Capital Association (Block and Sandner 2009; Huang and Zhan 2015). Potential biases, arising from the geographical focus of Crunchbase, have been considered and taken care of by cross-checking the completeness of the company list with other sources, e.g. CB Insights. Further, we conduct a web search to validate our data by comparing the unicorns' websites with the data in our sample. In particular, we check the unicorns' founding locations in order to reduce potential bias that might arise from any relocation developments. In addition, we compare the disclosed postmoney valuation of each company in the sample in the Crunchbase and CB Insight database. Thus, we cannot detect any systematic bias but confirm the high data 
coverage of Crunchbase. Numbers for GDP growth in respective countries were taken from World Bank's World Development Indicators database.

\subsection{Variables}

\subsubsection{Dependent variable}

We apply two dependent variables for our research. For the analysis of factors that drive the likelihood to achieve a valuation above one billion USD we take a dummy variable which equals one if the respective company is a unicorn and zero otherwise (logit model). This modeling is particularly necessary as no reliable post-money valuation is available for most ventures and ventures that are valued below one billion USD.

Further, we take the post-money valuation to examine influences in the group of unicorns (linear regression model). We consider that the post-money valuation of unicorns as dependent variable fits best our research purpose although we are one of the first studies using this variable as success measure. Another advantage of our selection is that the post-money valuation is a continuous variable compared to previously used binary variables, thus providing an information gain. However, the post-money valuation of ventures is only available in a reliable manner for unicorns. Hence, we apply this variable only for unicorns in the respective analysis but not for peers or analyses that include peers. Due to the high skewness of the post-money valuation in our sample, we apply the natural logarithm of the post-money valuation.

\subsubsection{Independent and control variables}

Historically, the age of an investor was argued to be a good proxy for the reputation of an investor. However, this does not consider any success-related components except the survival of an investor.

To overcome the shortcomings which arise from age as a reputation measure, recent studies apply new reputation indicators. Beside the total number of investments made by a VC firm, the share of investments exited via an IPO became a popular measure of investor reputation (Bottazzi et al. 2008; Nahata 2008; Jackson et al. 2012). This measure is based on the assumption that IPOs are the most favorable exit option for investors. Companies that undergo an IPO need to convince the public capital markets of their quality and offer on average abnormal high returns for their VC investors. Therefore, IPOs are typically the most profitable way to exit investments but the most complex way at the same time.

In order to test our hypothesis that more reputable investors increase the likelihood for ventures to achieve the unicorn status, we refer to the investor which acted as lead investor in the first (initial) funding round. Focusing on lead investors is in line with current research as the lead investors have the closest relationship with the portfolio company in investor syndicates and thus exert great influence (Wright et al. 2004; Krishnan et al. 2011; Li and Mahoney 2011). In addition, their equity stake usually exceeds that of the remaining investors. Further, focusing on 
the initial funding round is reasonable as early investors have a large influence on the venture's development due to their typically long investment history with the venture and due to their ability to shape the venture's strategy (Hsu 2004; Stayton and Mangematin 2018).

The reputation (Inv_IPO Share) was calculated following a similar approach like Nahata (2008) by taking the average of the yearly percentage share of IPOs backed by a specific investor compared to all IPOs in the same year. For calculating the reputation, we refer to a timespan from 1990 until 2018.

In addition, we include a dummy variable indicating whether the venture received funding by a CVC firm or not (CVCinvestor) in order to assess the influence of the latter and to test the hypothesis whether ventures that receive funding from CVC investors exhibit a higher likelihood to become a unicorn.

To answer the question whether the foundation of ventures within innovation clusters influences the likelihood to become a unicorn, we incorporate dummy variables in our analysis. These dummy variables equal one if the venture is located within the respective region and zero otherwise (SiliconValley_Target, Boston_Target, NewYork_Target, Beijingarea_Target, Shanghai_Target).

To address the question whether strong and aggressive growth is driving the valuation of unicorns, we use the number of add-on acquisitions (\#Addon_acquisitions) to account for non-organic growth as there is evidence for the existence of a "winner-takes-it-all" premium (Simon 2016; Stayton and Mangematin 2018) for industry/market-dominating ventures.

To account for additional influences on the likelihood for new ventures to become a unicorn, we include the following control variables in our model. A lot of recently founded ventures operate in internet-related businesses in a B2C setting ( $\mathrm{Li}$ and Mahoney 2011). Therefore, we include a dummy variable indicating if the respective unicorn's or peer's business model is related to the internet or mobile apps as well as a dummy variable that indicates if the unicorn or peer acts in the B2B sphere. The variable equals one if the company's business is app or internet related and zero otherwise (Internetorapprelated). The B2B variable $(B 2 B)$ equals one if the company operates in the B2B sphere and zero if the company operates a B2C business model. Further, we include a dummy variable that equals one if the respective unicorn or peer operates a platform business model and zero otherwise (Platform). In addition, we control for the founding team size (\#founders) following Bhawe et al. (2017) and Ratzinger et al. (2018) in order to account for the effects evolving from the diversity of founding teams (Eesley and Roberts 2012), particularly as founders' characteristics and team size have been identified as influencing factors in past research (Bernstein et al. 2017; Rungi et al. 2016).

We include the GDP growth in the year of founding (GDP_growth_founding) to control for general market effects on the respective founding behavior. Further, we control for the age at latest funding (Age). To control for the effect of overall economic conditions, we include the GDP growth during the latest funding round in the respective country (GDP_growth_latestfunding). 


\subsection{Descriptive statistics}

Table 1 presents descriptive statistics of the variables used in the empirical analysis of all unicorns we have identified (Panel A). Further, Table 1 presents descriptive statistics for unicorns and identified peers (Panel B) and for the respective peers (Panel C) separately. $T$-tests for the comparison of means indicate that unicorns and respective peers differ to some extent, depending on the variables considered in our analysis.

Unicorns are more often backed by CVC investors compared to non-unicorns. In addition, the share of IPO exits is considerably higher for unicorn's initial lead investors compared to non-unicorn lead investors. Comparing the entire unicorn sample of 235 cases with the relevant peers identified shows no significant difference.

\section{Empirical analysis and results}

As described, we conduct two types of analysis which are presented below, in order to examine our hypotheses. To test for multicollinearity of variables, we refer to the variance-inflation-factors (VIF). The mean VIF in all models is below an acceptable range of 10 , indicating that multicollinearity is not a major issue (Gujarati 2003).

\subsection{Logit model}

To test our hypotheses and in order to examine the factors that separate nonunicorns from ventures with a valuation of more than one billion USD, we conduct a logistic regression analysis in line with Jain (2001). Hence, we model the probability of a venture to become a unicorn depending on a set of control variables and our hypothesized effects regarding investor reputation, being placed in a cluster and the existence of CVCs among the investor group. Our model is therefore formalized as follows:

$$
\rho_{i}=P R\left[y_{i}=1 \mid x_{i}\right]=\Phi\left(\beta_{1}+\beta_{2} x_{i}\right)
$$

Here, $y_{i}$ is the occurrence of becoming a unicorn (0/1) depending on a ventures' characteristics $x_{i}$.

The results of the logistic regressions are presented in Table 2. Thereby, Panel A reports the results as marginal effects at the means, whereas Panel B reports the results as average marginal effects which is seen as superior when realistically interpreting the results. In model 1 to 5, we present the regressions for independent variables and controls separately, whereas model 6 contains the full model of all independent variables and controls. Since a valuation of more than one billion USD (unicorn) is indicated by a value of one, significantly positive coefficients denote an increase in the likelihood for ventures to become a unicorn. For all logit models, model fit was assessed by the Akaike Information Criterion (AIC) and the Bayesian Information Criterion (BIC). Thereby, lower levels represent a better model fit 


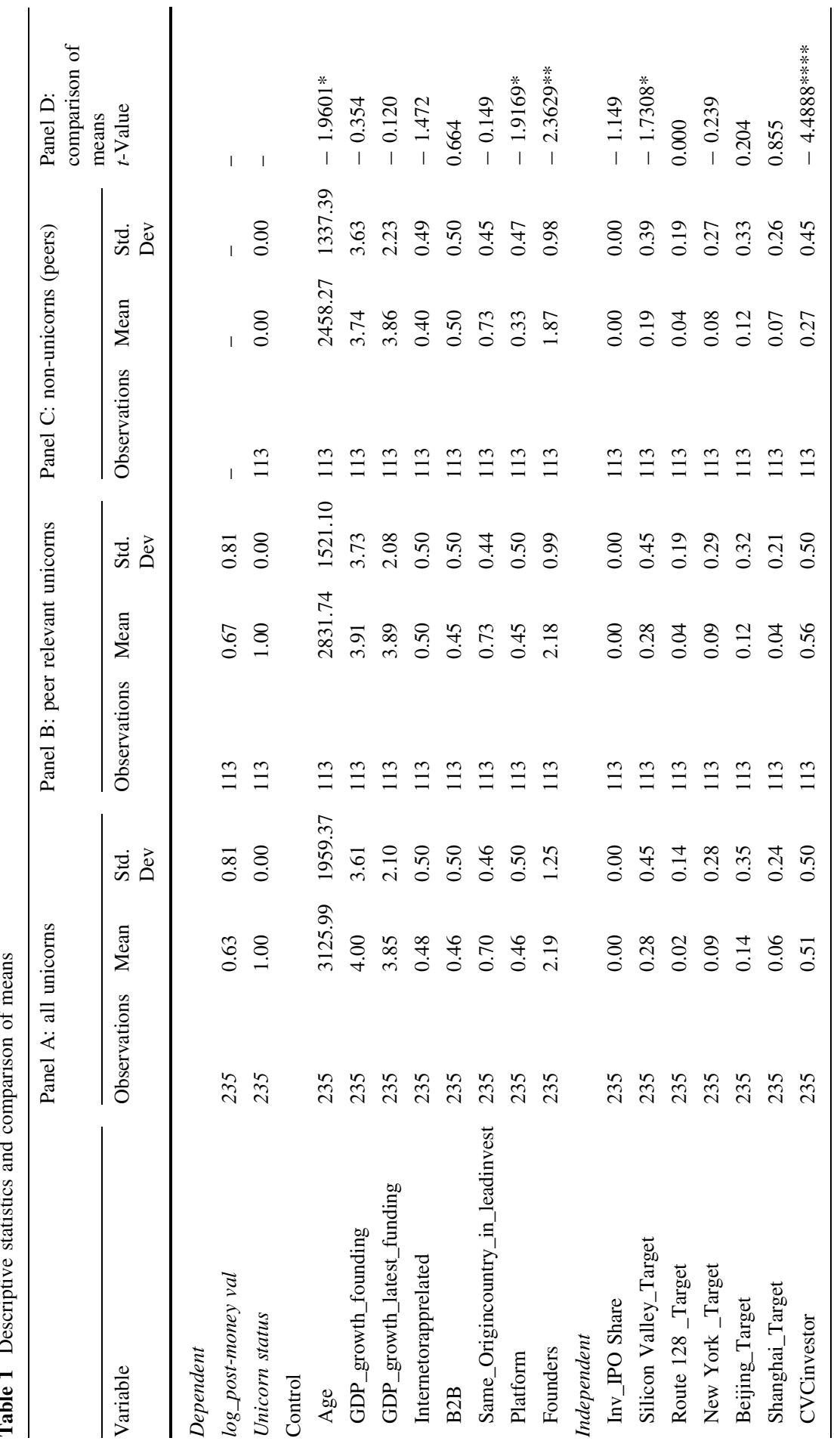




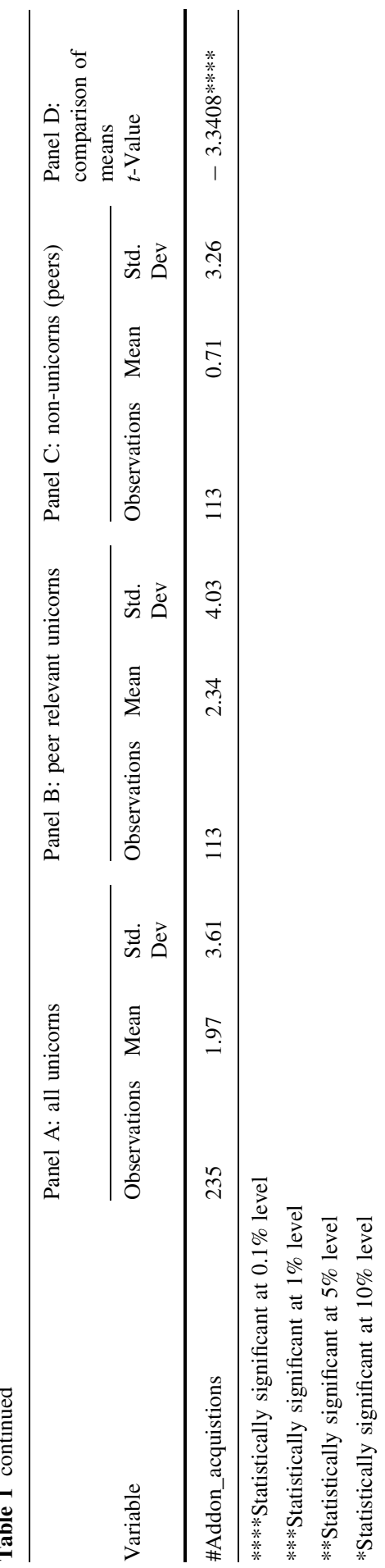




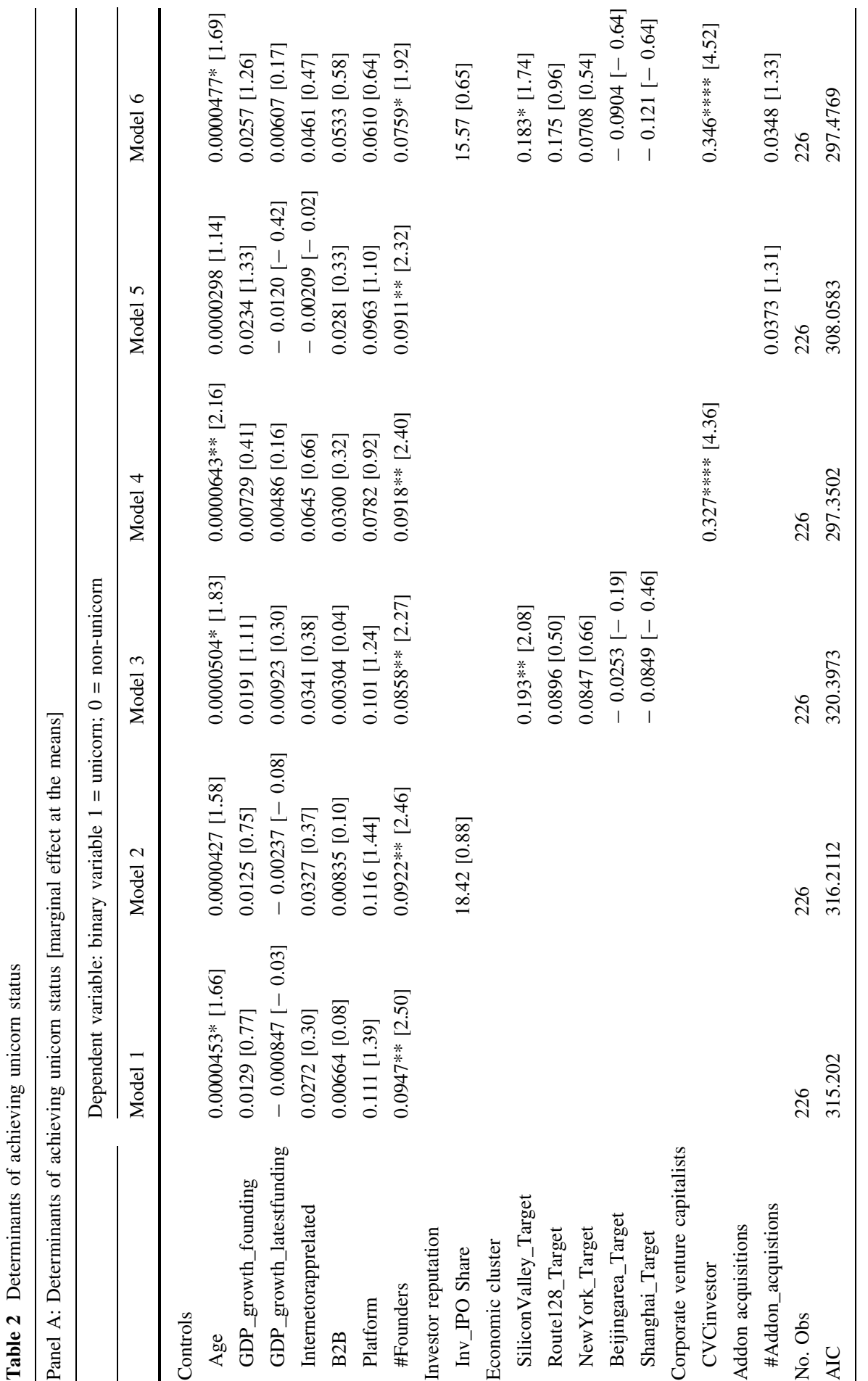




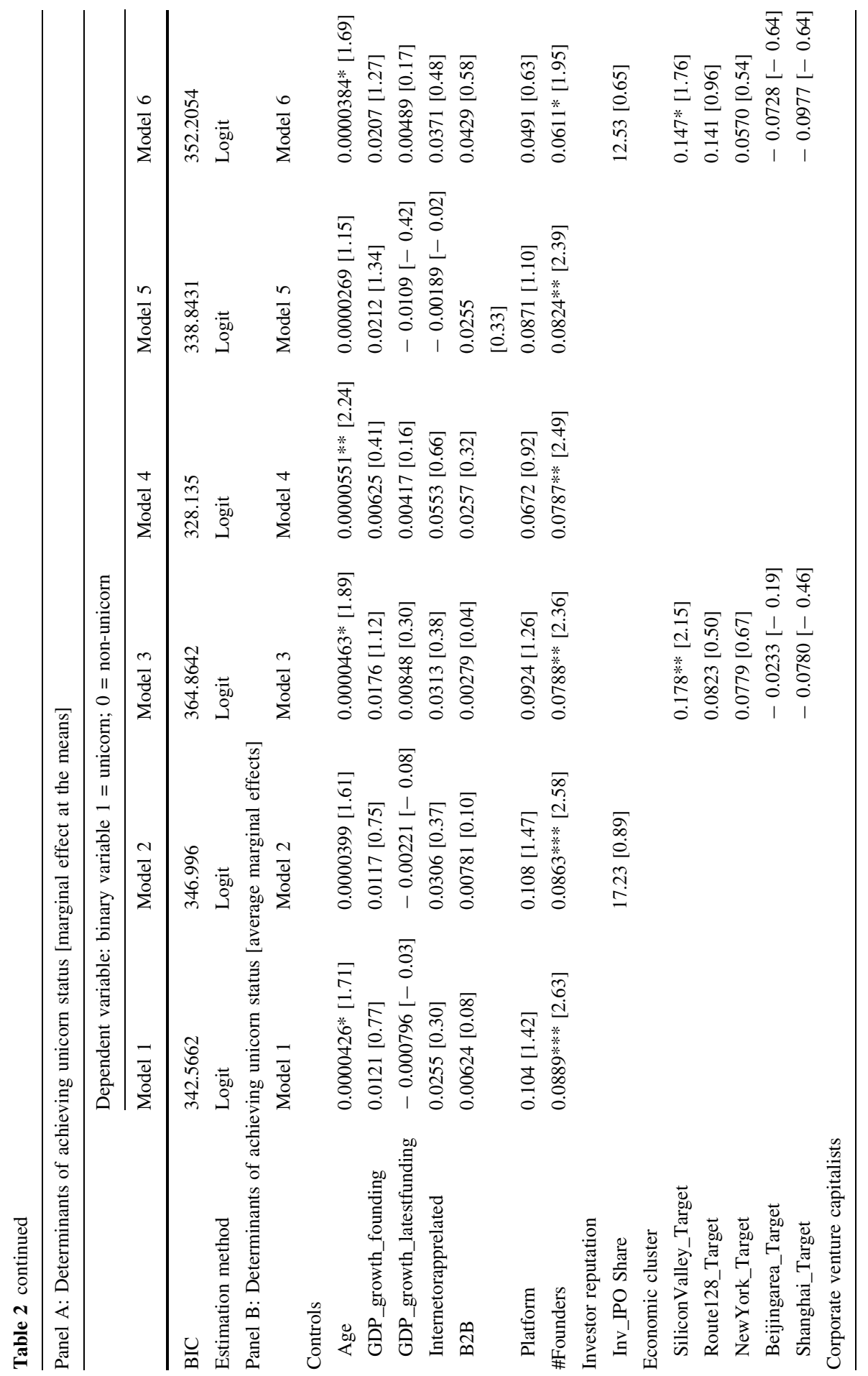




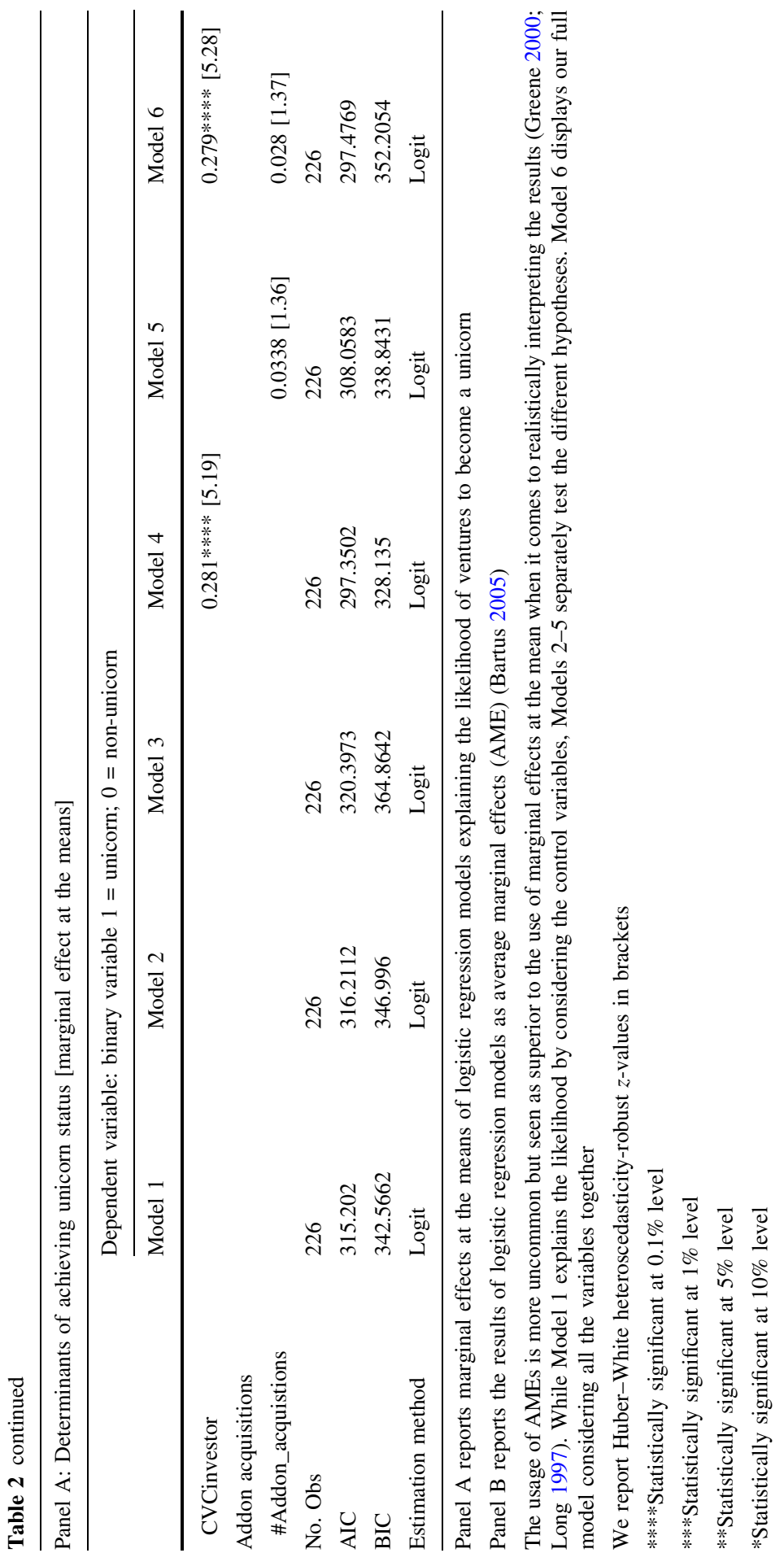


(Akaike 1998). In order to test our first hypothesis, we include investor reputation in our model. The logit estimates show that the likelihood to become a unicorn is positively impacted by the investor's reputation (Inv_IPO Share) when including our controls (model 2) as well as in the full model (model 6). Though, the effect remains statistically insignificant.

Reviewing the influence of being founded within a cluster presents ambiguous results. We find a significant (1\% level) positive relationship for the likelihood to become a unicorn for Silicon Valley based ventures (SiliconValley_Target) (model 3) which holds also in our full model (model 6). Significant effects from other clusters like Route 128 (Route128_Target) or Beijing (Beijing_Target) are not observable within our dataset. This result underlines to some extent the uniqueness of Silicon Valley when it comes to the foundation of innovative and successful ventures. In particular, it demonstrates that clusters exhibit different characteristics and finally different quality levels regarding the support of young ventures.

Furthermore, the logistic regression shows that the likelihood of becoming a unicorn is positively influenced by the existence of a CVC investor (CVC Investor). This effect is significant on a $0.1 \%$ level (model 4) and is line with hypothesis 3. Further, these findings persist in our full model (model 6) at the same significance level.

Finally, we cannot find any statistically significant effect that the number of addon acquisitions (\#Addon_acquistions) impacts the likelihood to become a unicorn, although the estimates show positive coefficients (model 5) which holds also in the full model (model 6).

In the full model of all independent and control variables taken together, the combination of effects becomes obvious. Although the average marginal effect does not consider the non-linear trend of the probability curve of logit regressions, the respective coefficients are more suitable to present a more vivid effect of the independent variables on the dependent variable than, for example, odds ratios (Hoetker 2007). Therefore, we present our results using average marginal effects in Table 2 panel B.

Within our full model, we see that the foundation of a venture in the Silicon Valley area (SiliconValley_Target) increases the predicted probability to become a unicorn, on average, by $14.7 \%$ (model 6). As already outlined, a statistically significant effect is only observable for Silicon Valley based ventures (5\% level). For ventures that are based in New York (New York_Target) or Route 128 area (Route128_Target) the model exhibits positive relationships but only on statistically insignificant levels. Surprisingly, we find negative coefficients for the predicted probably to become a unicorn (models 3 and 6) for ventures that have been founded in Beijing area (Beijingarea_Target) and Shanghai (Shanghaiarea_Target), though on statistically insignificant levels. Hence, the relevance of clusters seems to differ between different countries and the existing clusters possess different levels of development, whereas the Silicon Valley seems to be superior to others (Castilla 2003; Rosenthal and Strange 2003).

The predicted probability for ventures to become a unicorn is increased, on average by $28.1 \%$ (model 4 ) and $27.9 \%$ (model 6 ) if a corporate venture investor is part of the venture's investor group (CVCinvestor). This strong positive and highly 
significant $(0.1 \%$ level) effect supports hypothesis 3 and gives a clear indication that corporate investors either select superior ventures or provide better support for their portfolio companies than pure financial investors do. Interestingly, the number of founders (\#founders) shows a significant positive effect (5\% level in models 1 to 5 and $10 \%$ level in model 6) throughout all models. The positive impact of the number of founders on the predicted probability to become a unicorn hints on the widely stressed argument that a higher diversity within founding teams leads to higher performance (Beckman et al. 2007; Vogel et al. 2014).

\subsection{Linear regression}

In order to test our hypothesis that aggressive inorganic growth and subsequent addon acquisitions drive the post-money valuation, we conduct a linear OLS regression analysis applying robust estimators to cope with heteroscedastic data. We incorporate this separate analysis to test hypothesis 4 as this hypothesis presents a slightly different perspective than the remaining hypotheses. Hypothesis 4 considers the question which type of strategy investors value once a venture has achieved a unicorn status which differs from the question what drives the likelihood of ventures to become a unicorn. In order to avoid potential bias that might arise from the timing dynamics, as ventures do not execute add-on acquisitions at the very beginning of their lifetime but rather once they have become more mature and especially once they achieved a unicorn status, we decided that the post-money valuation as a dependent variable as well as a linear regression model is most appropriate following Seppä and Laamanen (2001) and Heughebaert and Manigart (2012). In particular, we use a linear regression model instead of a truncated regression model as we consider only unicorns as relevant for our research question and hence other ventures with a post-money valuation below one billion USD are not part of the sample. Due to the skewness of the post-money valuation, we apply the natural logarithm of this variable in our model. Subsequently, we derive the following regression equation:

$$
\begin{aligned}
\log (\text { post }- \text { money valuation })_{i}= & \alpha_{0}+\beta_{1} \text { investor reputation }_{i} \\
& +\sum_{k=2}^{7} \beta_{k} \text { cluster }_{i}+\beta_{8} \text { corporate venture investor }_{i} \\
& +\beta_{9} \text { addons } \\
& +\sum_{k=10}^{17} \beta_{k} \text { control variables }{ }_{k i}+\varepsilon_{i}
\end{aligned}
$$

The results of the linear regression are presented in Table 3. Basically, we consider the same variables as in our logit analysis but add the number of add-on acquisitions for the reasons outlined above. Model fit was assessed by adjusted $R$ square, whereas higher values determine a better model fit. As we apply the natural logarithm of the post-money valuation of unicorns as dependent variable, positive coefficients indicate a supporting influence between variables and the respective 


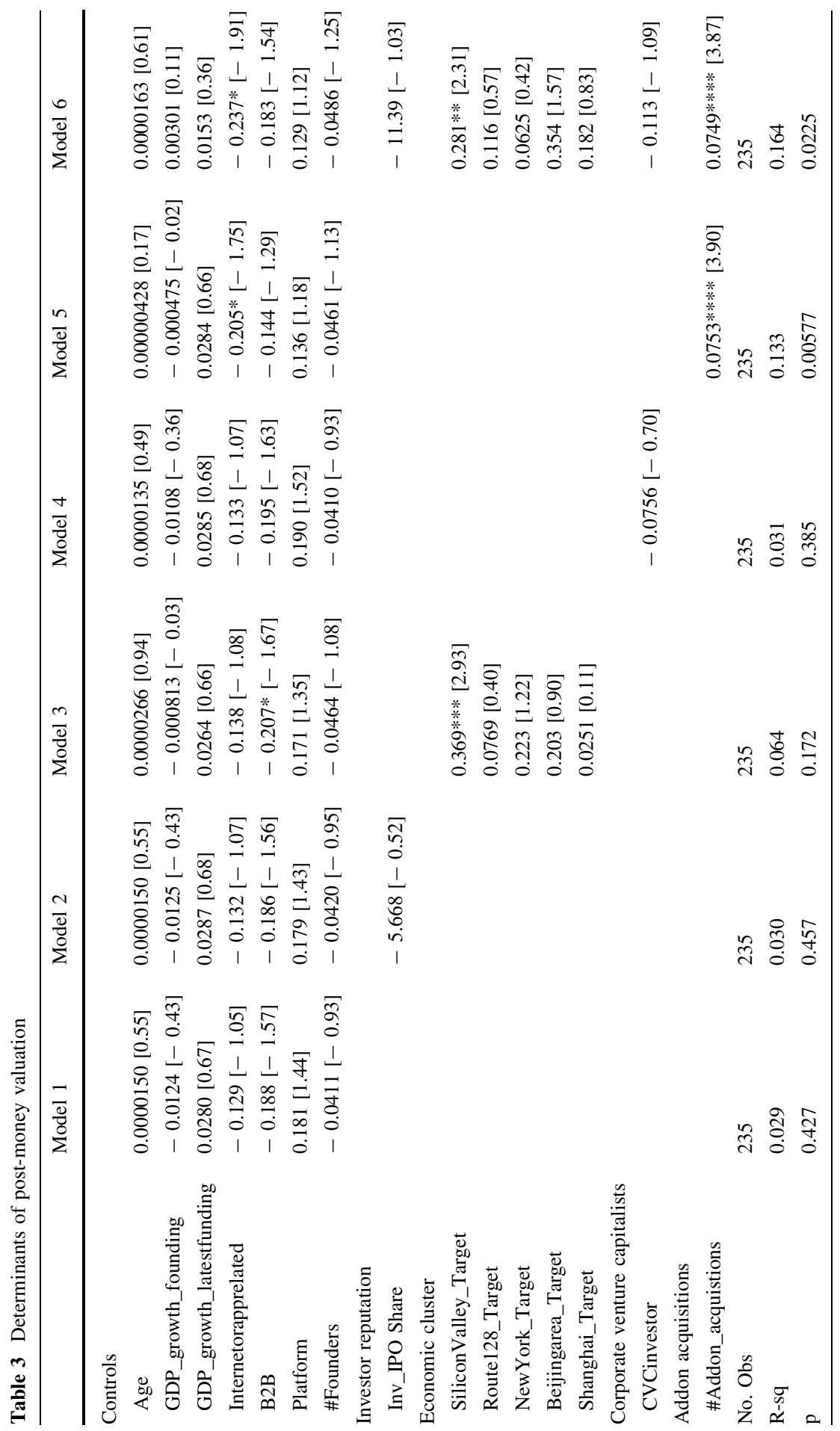




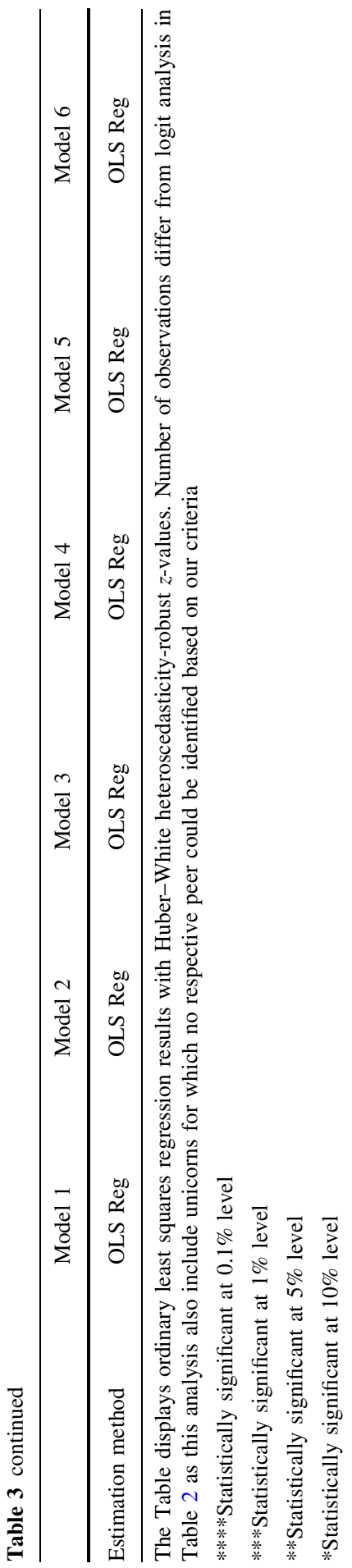


post-money valuation. For the sake of completeness, we present the same model structure as in the logit analysis but focus on the results of models 5 and 6 . Model 5 includes the number of add-on acquisitions while considering all control variables. Model 5 shows that the number of add-on acquisitions (\#Addon_acquisitions) is positively linked to the post-money valuation at a high significance level $(0.1 \%$ level). This effect also holds in the full model (model 6) and is in line with the oftencited assumption that the current venture and unicorn market is determined by a "winner-takes-it-all" approach and gives strong support for hypothesis 4 that aggressive and inorganic growth of unicorns is a value-determining factor. Although being outside of the focus of this analysis, we find no other significant effects that influence the post-money valuation of unicorns except for the foundation within the Silicon Valley area (SiliconValley_Target) which exhibits a positively significant effect (1\% level) (model 6). Obviously, unicorns that are based in the Silicon Valley area are valued higher by their investors independently form their age or general economic conditions as we have controlled for both factors.

\section{Extended analysis and limitations}

In order to check for extensions of our findings as well as to test the robustness of our results, we conduct additional analyses for the logit model as well as for the linear regression model which are not tabulated. In a first step, we include additional control variables in our model to test for unobserved effects. Following Zörgiebel (2016b), we include a dummy variable for unicorns which were founded during the financial crisis. In this context, the findings of Nanda and Rhodes-Kropf (2013) are worth to be considered. Both found evidence that companies that are founded during "cold" markets are more likely to perform an IPO and face a lower risk of bankruptcy (Nanda and Rhodes-Kropf 2013). Hence, we would expect that unicorns have been founded predominantly during such "cold" times. This additional variable does not show any significant effect on our results, neither in the logit nor in the linear regression model.

Second to test the robustness of the investor reputation results, we replace the IPO share as proxy for the investor reputation by the age of the investor following Nahata (2008). Further, we consider relationships between CVC investors and the venture's business model. In order to examine whether CVC investors are primarily interested in ventures that could help them to adapt their own business models to a changing economic environment, we test for moderating effects between the existence of a CVC investor and a special type of business model (platform and internet or app related). However, based on our data sample we do not find any significant effects concerning these assumptions.

Further, we perform our analysis limited to certain geographic regions. Therefore, we create subsamples of our original dataset based on the origin of the ventures and respective unicorns. As we apply two different datasets for models 1 and 2, we rerun our analysis on four subsamples (two for China and two for the US). We focus on these two countries as most unicorns are domiciled in these countries whereas the socio-political conditions are completely different and hence diverging 
effects might be observed. As a result in the logit model, we find a stronger influence of the existence of a CVC investor on the likelihood to become a unicorn for China-based unicorns and a positive significant effect for the number of founders for US-based ones. Both effects are statistically significant at a $0.1 \%$ and $1 \%$ level respectively. The remaining results of the logit analysis are in line with the results of our full sample (Table 3). Running again our linear regression model (Table 3) in order to test hypothesis 4 on China and US-based subsamples separately, reveals that the number of add-on acquisitions as a value-determining effect loses its significance for China-based unicorns. However, the sign of the effect remains positive. For the US-based subsample, the significance of the add-on effect increases.

Finally, we conduct again our two types of analysis (logit and linear regression) for those unicorns with a post-money valuation of more than two billion USD as unicorns valued exactly or slightly above one billion USD threshold might provide a bias as their valuation could be primarily artificially increased due to publicity reasons. The linear regression model, limited to the subsample of unicorns that are valued above two billion USD, shows consistent results with the full sample. For the logit regression, we observe that the significance of the Silicon Valley effect diminishes but remains significant on a low level (10\% level). We see two potential explanations for this effect. On the one hand, the Silicon Valley cluster support could primarily be important for less mature ventures or respective unicorns. On the other hand, one might argue that investors in the Silicon Valley area tend to provide ventures artificially high funding to enable them to pass the one billion USD threshold for publicity reasons which would increase the number of unicorns in Silicon Valley. However, we assume this explanation to be less relevant as the higher competition among VC investors within the Silicon Valley area should rather adjust such biased valuations.

Based on our analysis, we consider our results as robust in general. However, our robustness checks show that the degree of influence of considered factors varies depending on the origin and valuation level of the respective unicorn.

As every empirical study, our results are facing certain limitations. First, as unicorns are a very new phenomenon, the sample size is limited and there is currently no possibility to perform any long-term investigations. Closely linked to this limitation, scarcity of available data remains another limitation for our results which has also impacted previous studies (Homburg et al. 2014; Kaplan and Lerner 2016), due to the private ownership of unicorns. In particular, as the majority of all unicorns are headquartered in China or the US, there are no obligations for them to disclose annual reports or financials statements. Hence, our analysis is only able to measure the success of unicorns on a proxy level from an outside and third-person perspective.

Second, due to limited disclosure requirements, current research lacks detailed information on the ownership structure. To get deeper insights in the ownership and stock structure, it would be important to cope with the very common use of preferred liquidation rights in the field of unicorns. Especially unicorns with a valuation around one billion USD tend to sell stock with preferred liquidation rights to overcome the one billion USD valuation threshold for publicity reasons. But by 
selling stocks with preferred liquidation rights, the implicit and risk-adjusted valuation should be lower and probably in certain cases below one billion USD (Bartlett 2016).

Third, as the majority of unicorn investors are comparably young, they lack a proven track record. Hence, it is rather difficult to assess the performance of investors particularly in a long-term view.

Fourth, as per definition of unicorns, we include only VC-backed companies that are still operating. Following this approach, our results might face the risk of a survival bias. But by reviewing historical data on companies that achieved a unicorn status, it gets obvious that only very few of them dropped below a one billion USD valuation afterwards. Though, it is rather difficult how to deal with exited unicorns. However, most studies regard exited unicorns and venture-backed companies via IPO or an acquisition as the most favorable outcome for an investor (Bottazzi et al. 2008; Bengtsson and Wang 2010; Fitzgerald 2015). Taking both those arguments into consideration, effects from potential survival bias should be limited.

\section{Conclusion and discussion}

In this paper, we investigate the factors which drive the rising of VC-backed companies with a valuation of more than one billion USD, so called unicorns. Therefore, we follow a two-fold approach by examining factors that lead to a trespass of the one billion USD valuation threshold and the question which growth strategy is favored for unicorns by investors, separately. Based on the descriptive analyses, we observe that unicorns are a locally concentrated phenomenon with more than fifty percent based in the US. However, the share of China-based unicorns has been rapidly increasing during the last two years whereas activities in other countries remain on a comparably low level.

Based on our empirical results, we cannot find any significant influence of investor's reputation on the likelihood for ventures to become a unicorn. In particular, early investors have a higher influence as they are working in closer relationships with their portfolio companies and exhibit a stronger operational involvement (Hsu 2004; Stayton and Mangematin 2018). As we cannot find this effect to be significant in our analysis, we assume that this is due to the fact that the construct of investor reputation is hardly measurable. Hence, new measures of investor's reputation and quality should be considered in future research.

Besides that, we find limited support for hypothesis 2 that the foundation within a cluster increases the likelihood for ventures to become a unicorn as we find this effect to be significant only for the Silicon Valley area which indicates superior characteristics of this cluster in particular compared to other clusters in the US and China. Probably, this includes a self-reinforcing effect, as successful ventures and unicorns attract other ventures and investors, providing ultimately better infrastructure and leading to a highly innovative environment. The geographical proximity of VC investors might have an additional positive influence in this context on the likelihood of receiving further funding and allows investors to identify promising ventures earlier which results in locally concentrated unicorn 
births. Past research has identified that the political and regulatory environment has a direct effect on the likelihood of unicorn births (Wright et al. 2005; Safari 2013), however we see this effect as significant primarily on an inter-country level.

As we find further support for hypothesis 3 that CVC investors have a positive influence on the likelihood for ventures to become a unicorn, we are convinced that investors' strategic support and guidance might be one of the key differentiating factors besides financial support. Especially, as CVC are not renowned for their investment selection but for their operational support by providing production resources, market access, etc. (Chesbrough 2000; Narayanan et al. 2009; Chemmanur et al. 2014).

Finally, our results indicate that aggressive and inorganic growth strategies measured by the number of add-on acquisitions are driving the level of valuation and hence are a favored strategy from an investor's perspective. This finding confirms the assumption that investors accept growth rates as a proxy for value. As an extension to existing research (Kenney and Zysman 2019) this assumption does not hold only for platform-based business models but seems to be applicable to all unicorns. Furthermore, we find that inorganic growth is fostered by investors as we do not find any significant impact that add-on acquisitions increase the likelihood to become a unicorn per se but only that these drive post-money valuation levels. Of course, this implies that investors take the availability of potential add-on targets into consideration when investing in unicorns.

As profitability fades into the background and investors are willing to absorb high exceptional losses, we conclude that growth is one of the key drivers for valuation and return on investment based on the assumption that today's unicorns will turn in highly profitable companies some time in the future following role models like Facebook.

By comparing the results of both analyses (Logit and OLS regression) additional detailed conclusions can be drawn on the interconnection of the factors that drive the likelihood to become a unicorn and factors that influence the post-money valuation.

Our results show that the foundation in the Silicon Valley area has a positive impact on the likelihood to become a unicorn as well as on the post-money valuation. This underpins the exceptional position of the Silicon Valley cluster in today's unicorn ecosystem. However, whereas we assume that good entrepreneurial conditions for high quality ventures i.e. best-in-class research institutes, strong investor network, skilled labor force etc. have a positive impact on the likelihood to become a unicorn, the post-money valuation levels are probably also driven by the existence of large VC investors in the Silicon Valley area. With extremely high levels of committed capital, they are able to participate in or to drive multibillion funding rounds.

Second, as we cannot find any significant influence of CVC investors on the postmoney valuation but a strong positive impact on the likelihood to become a unicorn, this finding indicates that ventures benefit primarily from CVC support before they become a high-valued unicorn which is in line with the findings of Park and Steensma (2012). Furthermore, this finding indicates that CVC investors act as a signal to other market participants besides providing operational and financial 
support. However, we conclude that this effect decreases once the venture has achieved a unicorn valuation because unicorns have usually already established a strong footprint with regard to market and stakeholder awareness. In addition, the influence of an individual investor decreases usually during follow-on funding rounds due to larger investor universes and diluted shareholdings. This effect is in line with our result that the existence of a CVC investor does not directly impact the post-money valuation of unicorns.

Third, the number of add-on acquisitions, i.e. an inorganic growth strategy, only seems to influence the post-money valuation whereas we do not find any significant impact on the overall probability to become a unicorn. We assume that the major reason for this effect is that unicorns need to achieve a certain level of maturity in terms of organizational development and funding before acquisitions are executed on a large scale. That means investors value acquisitions and strong growth rates predominantly in later funding rounds and hence increase their funding and subsequently the post-money valuation. Furthermore, the larger funding rounds prepare the ground for additional large acquisitions which enable unicorns to gain considerable market shares and hence to boost their post-money valuation. Clearly, this effect comes only limited into play when assessing the likelihood of ventures to become a unicorn. To some extent this effect can be regarded as a self-enforcing process once the venture or unicorn has reached a certain threshold in terms of market share and received funding. At this point, investors seem to be willing to finance the further development of the unicorn towards an absolute market leader.

Our results contribute to the existing research in several ways. First, we add to the literature on investor quality and their subsequently assumed support for their portfolio companies. Whereas past research found majorly a strong relation between the reputation, i.e. quality of an investor, and the success probability of its ventures regardless of the ventures' state (Megginson and Weiss 1991; Hsu 2004; Lee et al. 2011), we add a more detailed view on this. By demystifying the role of the initial investor's reputation, we show that additional research is required to differentiate the relation between portfolio companies and investors depending on the ventures' lifecycle position.

Second, we contribute to the literature on spatial distribution of economic success. A common theme in this literature stream is that economic or innovation clusters support ventures and entrepreneurs (Sternberg and Litzenberger 2004; Romanelli and Khessina 2005; Nicotra et al. 2018). Based on our analysis, we add to this that large geographical differences exist between such clusters. Our results support the notion that a well-working ecosystem, like the Silicon Valley, fosters its own success by boosting unicorns and startups find enough established VC investors to collect enough money for reaching a unicorn status, hence creating a vicious cycle. Furthermore, the size of the startup and the level of startup's maturity seems to be decisive when assessing the support potential of a cluster.

Third, we add to the literature on CVC. The existing literature has already described the benefits of CVC extensively (Park and Steensma 2012; Rossi et al. 2017). However, our results highlight the interrelation between corporate investments and the success probability of ventures even for the most successful type of ventures, i.e. unicorns. 
Lastly, we add to the valuation literature and more specific to the venture valuation literature. The venture's strategy has already been considered as important for the valuation in past research (Festel et al. 2013; Salamzadeh and Hiroko 2015; Meglio et al. 2017). Our results confirm thereby that growth is one of the most important and dominant factors concerning a startup's valuation, an aspect which is accounted for by the valuation of investors.

Besides the theoretical contribution of our findings, we see also clear practical implications. Our results enable decision-makers and governments to adjust their policy in order to foster the emergence and growth of ventures. Further, our analyses have implications for founders and key executives of ventures as the results can be considered when conducting funding rounds and subsequently choosing new investors. In addition, our results help founders and entrepreneurs when it comes to the question of choosing the right location as well as finding the right strategy for their venture in order to maximize the likelihood to become a member in the club of unicorns if they wish so.

The main question that remains in current research is how the valuation of unicorns will develop in the future and if there will be any impairments necessary or if the rise of unicorns will remain as an ongoing development (Fenwick and Vermeulen 2015). In particular, the majority of all unicorns is still showing high cash-burn rates and negligible or only intangible assets (Zimmerman 2016). Further, some of the current unicorns even lack a business model and generate only minor revenues but offer just great customer growth rates or growth potential. In fact, it will turn out if the current unicorn valuations are justified when the VC investors exit the unicorns via an IPO or private sale. However, there is certain consensus among venture capitalists that today's unicorns are overvalued (Gompers et al. 2016) especially as today's unicorns seem to be different from previous ones like Google or Facebook, which in fact were cash-generative and with a positive income in an early status (Cable 2017). Given that and taking into consideration that we were facing a slowdown of unicorn births in 2018, certain studies assume that we achieved already the peak of the unicorn trend (CB Insights August 4, 2016) or stand right in front of the bust of a unicorn bubble (Fitzgerald 2015; Vardi 2016).

However, the further development could rather be driven by the general VC inflow which is highly linked to general financial capital markets ( $\mathrm{Li}$ and Mahoney 2011). Hence, high capital inflows to the VC market could enable further private initial public offerings (PIPO) which in some sectors exceed public IPOs in both frequency and dollar volume (Brown and Wiles 2015).

In the course of our study, we found an additional phenomenon which could be hardly assessed due to the available data. Currently, the role of preferred liquidity stock and its impact on valuation is rather unclear as only limited research has been conducted so far in this field. However, there is a clear indication that this special stock class has a strong influence especially for the unicorns with a valuation slightly above one billion USD and hence it could be worth to consider that phenomenon in future research purposes (Zörgiebel 2016a). This holds also for special term sheets that are used in venture financing rounds which are favorable for investors in particular in later funding rounds but which are usually detrimental to the interests of founders and early stage investors. However, research on those 
aspects is limited due to scarcity of data and particularly financials in the field of unicorn research. Overcoming this hurdle can open additional room for research purposes on a company level which should be linked with an investigation of the preferred liquidity stock phenomenon.

However, it remains unclear if growth and increasing market shares will remain key drivers for investor's valuation in the future. As we include only the initial investor, the question what drives the future valuation has to be left for future research. Nevertheless, despite of any potential valuation issues, there is a high probability that some of the unicorns will develop and offer very disruptive technologies (Fenwick and Vermeulen 2015) which will change traditional business models for ever.

Open Access This article is licensed under a Creative Commons Attribution 4.0 International License, which permits use, sharing, adaptation, distribution and reproduction in any medium or format, as long as you give appropriate credit to the original author(s) and the source, provide a link to the Creative Commons licence, and indicate if changes were made. The images or other third party material in this article are included in the article's Creative Commons licence, unless indicated otherwise in a credit line to the material. If material is not included in the article's Creative Commons licence and your intended use is not permitted by statutory regulation or exceeds the permitted use, you will need to obtain permission directly from the copyright holder. To view a copy of this licence, visit http:// creativecommons.org/licenses/by/4.0/.

\section{References}

Achleitner, A.-K., Engel, N., and Reiner, U. 2013. The performance of venture capital investments: Do investors overreact? Review of Financial Economics 22 (1): 20-35.

Achleitner, A.-K., Braun, R., Lutz, E., and Tappeiner, F. 2018. Private equity group reputation and financing structures in German leveraged buyouts. Journal of Business Economics 88 (3-4): 363-392.

Akaike, H. 1998. Information Theory and an Extension of the Maximum Likelihood Principle. In Selected Papers of Hirotugu Akaike, ed. E. Parzen, K. Tanabe, and G. Kitagawa, 199-213. New York: Springer.

Alexy, O.T., Block, J.H., Sandner, P., and Ter Wal, A.L.J. 2012. Social capital of venture capitalists and start-up funding. Small Business Economics 39 (4): 835-851.

Alperovych, Y., and Hübner, G. 2011. Incremental Impact of Venture Capital Financing. Liège: University of Liège, HEC Management School.

Alvarez-Garrido, E., and Dushnitsky, G. 2016. Are entrepreneurial venture's innovation rates sensitive to investor complementary assets?: Comparing biotech ventures backed by corporate and independent VCs. Strategic Management Journal 37 (5): 819-834.

Bartus, T. 2005. Estimation of Marginal Effects using Margeff. The Stata Journal 5 (3): 309-329.

Bartlett, R.P. 2016. A Founder's Guide to Unicorn Creation: How Liquidation Preferences in M\&A Transactions Affect Start-up Valuation. In Research Handbook on Mergers and Acquisitions, ed. C.A. Hill and S.D. Solomon. Cheltenham: Edward Elgar Publishing.

Beckman, C.M., Burton, M.D., and O'Reilly, C. 2007. Early teams: The impact of team demography on VC financing and going public. Journal of Business Venturing 22 (2): 147-173.

Bengtsson, O., and F. Wang. 2010. What Matters in Venture Capital Evidence from Entrepreneurs Stated Preferences. Financial Management 39 (4): 1367-1401.

Bergemann, D., Hege, U., and Peng, P. 2008. Venture Capital and Sequential Investments: Discussion paper, YALE UNIVERSITY.

Bernstein, S., Giroud, X., and Townsend, R.R. 2016. The Impact of Venture Capital Monitoring. The Journal of Finance 71 (4): 1591-1622.

Bernstein, S., Korteweg, A., and Laws, K. 2017. Attracting Early-Stage Investors: Evidence from a Randomized Field Experiment. The Journal of Finance 72 (2): 509-538. 
Bhawe, N., Gupta, V.K., and Pollack, J.M. 2017. Founder exits and firm performance: An exploratory study. Journal of Business Venturing Insights 8: 114-122.

Block, J.H., and Sandner, P. 2009. What is the effect of the financial crisis on venture capital financing?: Empirical evidence from US Internet start-ups. Venture Capital 11 (4): 295-309.

Block, J.H., Fisch, C.O., Hahn, A., and Sandner, P.G. 2015. Why do SMEs file trademarks?: Insights from firms in innovative industries. Research Policy 44 (10): 1915-1930.

Block, J.H., Colombo, M.G., Cumming, D.J., and Vismara, S. 2018. New players in entrepreneurial finance and why they are there. Small Business Economics 50 (2): 239-250.

Bonini, S., Alkan, S., and Salvi, A. 2012. The Effects of Venture Capitalists on the Governance of Firms. Corporate Governance: An International Review 20 (1): 21-45.

Borell, M., and Heger, D. 2013. Sources of Value Creation Through Private Equity-Backed Mergers and Acquisitions: The Case of Buy-and-Build Strategies. ZEW -Centre for European Economic Research Discussion Paper No. 13-094

Bottazzi, L., Darin, M., and Hellmann, T. 2008. Who are the active investors?: Evidence from venture capital. Journal of Financial Economics 89 (3): 488-512.

Breuer, W., and Pinkwart, A. 2018. Venture capital and private equity finance as key determinants of economic development. Journal of Business Economics 88 (3-4): 319-324.

Brown, K.C., and Wiles, K.W. 2015. In Search of Unicorns: Private IPOs and the Changing Markets for Private Equity Investments and Corporate Control. Journal of Applied Corporate Finance 27 (3): 34-48.

Bygrave, W. D., and Timmons, J. 1992. Venture Capital at the Crossroads. University of Illinois at Urbana-Champaign's Academy for Entrepreneurial Leadership Historical Research Reference in Entrepreneurship.

Cable, A.J.B. 2017. Fool's Gold? Equity Compensation \& the Mature Startup. Virginia Law and Business Review 615 (11): 615-643.

Calcagnini, G., Favaretto, I., Giombini, G., Perugini, F., and Rombaldoni, R. 2016. The role of universities in the location of innovative start-ups. The Journal of Technology Transfer 41 (4): 670-693.

Carlsson, B. 2002. Institutions, Entrepreneurship, and Growth: Biomedicine and Polymers in Sweden and Ohio. Small Business Economics 19: 105-121.

Castilla, E.J. 2003. Networks of venture capital firms in Silicon Valley. International Journal of Technology Management 25 (1): 113-135.

CB Insights. 2016. Research Briefs: Unicorn Data: A data-driven look at private companies valued over $\$ 1$ billion.

CB Insights. 2018. The Global Unicorn Club (including whisper valuations) Current Private Companies Valued At \$1B+. https://www.cbinsights.com/research-unicorn-companies. Accessed 4 Nov 2018.

Chemmanur, T.J., Loutskina, E., and Tian, X. 2014. Corporate Venture Capital, Value Creation, and Innovation. Review of Financial Studies 27 (8): 2434-2473.

Chesbrough, H.W. 2000. Designing Corporate Ventures in the Shadow of Private Venture Capital. California Management Review 42 (3): 31-49.

Chesbrough, H.W. 2002. Making Sense of Corporate Venture Capital. Harvard Business Review 80 (3): 90-99.

Croce, A., Guerini, M. and Ughetto, E. 2016. Angel Financing and the Performance of High-Tech StartUps. Journal of Small Business Management 56 (2): 1-21.

Cumming, D., and Dai, N. 2011. Fund size, limited attention and valuation of venture capital backed firms. Journal of Empirical Finance 18 (1): 2-15.

Da Rin, M., Hellmann, T., and Puri, M.L. 2011. A Survey of Venture Capital Research: CentER Discussion Paper, Tilburg University.

Das, A., and Kapil, S. 2015. Inorganic growth of technology sector firms in emerging markets. International Journal of Emerging Markets 10 (1): 52-72.

Delgado, M., Porter, M.E., and Stern, S. 2010. Clusters and entrepreneurship. Journal of Economic Geography 10 (4): 495-518.

Dias, R.D.S., and Macedo, M.A.D.S. 2016. Private Equity and Venture Capital Funds: What Drives the Demand and Supply? BAR Brazilian Administration Review 13 (2): 1-21.

Divan, D. 2016. What's the Difference Between a US\$0 Million and a US\$0 Billion Company? IEEE Power Electronics Magazine 3 (1): 69-70.

Ebbers, J.J., and Wijnberg, N.M. 2012. Nascent ventures competing for start-up capital: Matching reputations and investors. Journal of Business Venturing 27 (3): 372-384. 
Eesley, C.E., and Roberts, E.B. 2012. Are you experienced or are you talented?: when does innate talent versus experience explain entrepreneurial performance? Strategic Entrepreneurship Journal 6 (3): 207-219.

Feldman, M.P. 2001. The entrepreneurial event revisited: firm formation in a regional context. Industrial and Corporate Change 10 (4): 861-891.

Fenwick, M., and Vermeulen, E.P.M. 2015. The new firm: staying relevant, unique and competitive. European Business Organization Law Review 16 (4): 595-623.

Ferrary, M., and Granovetter, M. 2009. The role of venture capital firms in Silicon Valley's complex innovation network. Economy and Society 38 (2): 326-359.

Festel, G., Wuermseher, M., and Cattaneo, G. 2013. Valuation of Early Stage High-tech Start-up Companies. International Journal of Business 18 (3): 217-231.

Filloux, F. 2014. The Ripple Effects of Disruptive Models. https://mondaynote.com/the-ripple-effects-ofdisruptive-models-b9eb56407f6b\#.6rlhy5fy7. Accessed 14 Mar 2017.

Fitzgerald, M. 2015. Venture Capital. SAGE Business Researcher.

Gaba, V., and Meyer, A.D. 2008. Crossing the organizational species barrier: How venture capital practices infiltrated the information technology sector. Academy of Management Journal 51 (5): 976-998.

Galloway, T.L., Miller, D.R., Sahaym, A., and Arthurs, J.D. 2017. Exploring the innovation strategies of young firms: Corporate venture capital and venture capital impact on alliance innovation strategy. Journal of Business Research 71: 55-65.

Gilbert, B.A., McDougall, P.P., and Audretsch, D.B. 2008. Clusters, knowledge spillovers and new venture performance: An empirical examination. Journal of Business Venturing 23 (4): 405-422.

Gompers, P., and Lerner, J. 2000. Money chasing deals? The impact of fund inflows on private equity valuations. Journal of Financial Economics 55: 281-325.

Gompers, P., Kovner, A., Lerner, J., and Scharfstein, D. 2006. Skill vs. Luck in Entrepreneurship and Venture Capital: Evidence from Serial Entrepreneurs. Cambridge: National Bureau of Economic Research.

Gompers, P., Gornall, W., Kaplan, S., and Strebulaev, I. 2016. How Do Venture Capitalists Make Decisions?. NBER Working Paper Series, No. 22587.

Greene, H.W. 2000. Econometric analysis. 4. ed, internat ed. Upper Saddle River, NJ: Prentice Hall Internat.

Grilli, L., and Murtinu, S. 2014. Government, venture capital and the growth of European high-tech entrepreneurial firms. Research Policy 43 (9): 1523-1543.

Groh, A.P., and von Liechtenstein, H. 2011. The First Step of the Capital Flow from Institutions to Entrepreneurs: The Criteria for Sorting Venture Capital Funds. European Financial Management 17 (3): 532-559.

Gujarati, D.N. 2003. Basic econometrics. Boston: McGraw-Hill.

Guo, B., Lou, Y., and Pérez-Castrillo, D. 2015. Investment, Duration, and Exit Strategies for Corporate and Independent Venture Capital-Backed Start-Ups. Journal of Economics and Management Strategy 24 (2): 415-455.

Haagen, F. 2008. The role of smart money: What drives venture capital support and interference within biotechnology ventures? Zeitschrift für Betriebswirtschaft 78 (4): 397-421.

Hammer, B., Hinrichs, H., and Schweizer, D. 2016. Buy and Build Strategies in Private Equity: Boost or Transformation? SSRN Electronic Journal.

Hammer, B., Knauer, A., Pflücke, M., and Schwetzler, B. 2017. Inorganic growth strategies and the evolution of the private equity business model. Journal of Corporate Finance 45: 31-63.

Häussler, C., Harhoff, D., Müller, E. 2008. To Be Financed or Not - The Role of Patents for Venture Capital Financing. Working paper, ZEW - Centre for European Economic Research Discussion Paper No. 09-003.

Hellmann, T., and Puri, M. 2002. Venture Capital and the Professionalization of Start-Up Firms: Empirical Evidence. The Journal of Finance 57 (1): 169-197.

Heughebaert, A., and Manigart, S. 2012. Firm Valuation in Venture Capital Financing Rounds: The Role of Investor Bargaining Power. Journal of Business Finance and Accounting 39 (3-4): 500-530.

Hoetker, G. 2007. The use of logit and probit models in strategic management research: Critical issues. Strategic Management Journal 28 (4): 331-343.

Homburg, C., Hahn, A., Bornemann, T., and Sandner, P. 2014. The Role of Chief Marketing Officers for Venture Capital Funding: Endowing New Ventures with Marketing Legitimacy. Journal of Marketing Research 51 (5): 625-644. 
Hsu, D.H. 2004. What Do Entrepreneurs Pay for Venture Capital Affiliation? The Journal of Finance 59 (4): 1805-1844.

Huang, J., and Zhan, S. 2015. With a Little Help of My (Former) Employer: Past Employment and Entrepreneurs' External Financing. Academy of Management Proceedings 2015 (1): 1-29.

Inderst, R., and Müller, H.M. 2004. The effect of capital market characteristics on the value of start-up firms. Journal of Financial Economics 72 (2): 319-356.

Jackson, W.E., Bates, T., and Bradford, W.D. 2012. Does venture capitalist activism improve investment performance? Journal of Business Venturing 27 (3): 342-354.

Jain, B.A. 2001. Predictors of performance of venture capitalist-backed organizations. Journal of Business Research 52 (3): 223-233.

Kaplan, S.N., and Lerner, J. 2016. Venture Capital Data: Opportunities and Challenges. Cambridge: National Bureau of Economic Research.

Kaplan, S.N., and Strömberg, P. 2000. How Do Venture Capitalists Choose Investments?: Working paper, University of Chicago.

Kelly, R., and Kim, H. 2018. Venture capital as a catalyst for commercialization and high growth. The Journal of Technology Transfer 43 (6): 1466-1492.

Kenney, M., and Zysman, J. 2019. Unicorns, Cheshire cats, and the new dilemmas of entrepreneurial finance. Venture Capital 21 (1): 35-50.

Kensinger, J.W., Martin, J.D., and Petty, J.W. 2000. Harvesting Value From Entrepreneurial Success. Journal of Applied Corporate Finance 12 (4): 81-93.

Khan, J.H., and Ghani, J.A. 2004. Clusters and Entrepreneurship: Implications for Innovation in a Developing Economy. Journal of Developmental Entrepeneurship 9 (3): 221-238.

Krishnan, C.N.V., Ivanov, V.I., Masulis, R.W., and Singh, A.K. 2011. Venture Capital Reputation, PostIPO Performance, and Corporate Governance. The Journal of Financial and Quantitive Analysis 46 (5): 1295-1333.

Lee, P.M., Pollock, T.G., and Jin, K. 2011. The contingent value of venture capitalist reputation. Strategic Organization 9 (1): 33-69.

Lemarié, S., Mangematin, V., and Torre, A. 2001. Is the Creation and Development of Biotech SMEs Localised? Conclusions Drawn from the French Case. Small Business Economics 17: 61-76.

Lerner, J. 2010. The future of public efforts to boost entrepreneurship and venture capital. Small Business Economics 35 (3): 255-264.

Leydesdorff, L., and Etzkowitz, H. 1996. Emergence of a Triple Helix of university-industry-government relations. Science and Public Policy 23 (5): 279-286.

Li, Y., and Mahoney, J.T. 2011. When are venture capital projects initiated? Journal of Business Venturing 26 (2): 239-254.

Lindsey, L. 2002. The Venture Capital Keiretsu Effect: An Empirical Analysis of Strategic Alliances Among Portfolio Firms: SIEPR Discussion Paper No. 02-17, Stanford University.

Long, S.J. 1997. Regression models for categorical and limited dependent variables. Thousand Oaks, Calif.: Sage Publ.

Long, C., and Zhang, X. 2011. Cluster-based industrialization in China: Financing and performance. Journal of International Economics 84 (1): 112-123.

MacMillan, I.C., Kulow, D.M., and Khoylian, R. 1989. Venture Capitalists' involvement in their investments: Extend and performance. Journal of Business Venturing 27 (4): 27-47.

Maschke, K., and zu Knyphausen-Aufseß, D. 2012. How the Entrepreneurial Top Management Team Setup Influences Firm Performance and the Ability to Raise Capital: A Literature Review. Business Research 5 (1): 83-123.

Mason, C., and Brown, R. 2014. Entrepreneurial Ecosystems And Growth Oriented Entrepreneurship. Paris: OECD.

Megginson, W.L., and Weiss, K.A. 1991. Venture Capitalist Certification in Initial Public Offerings. The Journal of Finance 46 (3): 879-903.

Meglio, O., Mocciaro Li Destri, A., and Capasso, A. 2017. Fostering Dynamic Growth in New Ventures through Venture Capital: Conceptualizing Venture Capital Capabilities. Long Range Planning 50 (4): 518-530.

Milanesi, D. 2012. Secondary Trading of Private Company Shares: New Opportunities and Challenges. SSRN Electronic Journal.

Miloud, T., Aspelund, A., and Cabrol, M. 2012. Startup valuation by venture capitalists: An empirical study. Venture Capital 14 (2-3): 151-174.

Morck, R. (ed.). 2000. Concentrated corporate ownership. Chicago: University of Chicago Press. 
Nahata, R. 2008. Venture capital reputation and investment performance. Journal of Financial Economics 90 (2): $127-151$.

Nanda, R., and Rhodes-Kropf, M. 2013. Investment cycles and startup innovation. Journal of Financial Economics 110 (2): 403-418.

Narayanan, V.K., Yang, Y., and Zahra, S.A. 2009. Corporate venturing and value creation: A review and proposed framework. Research Policy 38 (1): 58-76.

Nicotra, M., Romano, M., Del Giudice, M., and Schillaci, C.E. 2018. The causal relation between entrepreneurial ecosystem and productive entrepreneurship: a measurement framework. The Journal of Technology Transfer 43 (3): 640-673.

Paik, Y., and Woo, H. 2017. The Effects of Corporate Venture Capital, Founder Incumbency, and Their Interaction on Entrepreneurial Firms' R\&D Investment Strategies. Organization Science 28 (4): 670-689.

Panetti, E., Parmentola, A., Ferretti, M., and Reynolds, E.B. 2019. Exploring the relational dimension in a smart innovation ecosystem: A comprehensive framework to define the network structure and the network portfolio. The Journal of Technology Transfer 49 (1): 1-22.

Park, H.D., and Steensma, H.K. 2012. When does corporate venture capital add value for new ventures? Strategic Management Journal 33 (1): 1-22.

Park, H.D., and Steensma, H.K. 2013. The Selection and Nurturing Effects of Corporate Investors on New Venture Innovativeness. Strategic Entrepreneurship Journal 7 (4): 311-330.

Phalippou, L. 2010. Venture capital funds: Flow-performance relationship and performance persistence. Journal of Banking \& Finance 34 (3): 568-577.

Puri, M., and Zarutskie, R. 2012. On the Life Cycle Dynamics of Venture-Capital- and Non-VentureCapital-Financed Firms. The Journal of Finance 67 (6): 2247-2293.

Ramadan, A., Lochheard, C., and Peterson, D. 2014. Behind Uber's soaring value I Fortune.com. https:// fortune.com/2014/12/11/behind-ubers-soaring-value/. Accessed 14 Mar 2017.

Ratzinger, D., Amess, K., Greenman, A., and Mosey, S. 2018. The impact of digital start-up founders' higher education on reaching equity investment milestones. The Journal of Technology Transfer 43 (3): 760-778.

Rindova, V.P., Williamson, I.O., Petkova, A.P., and Sever, J.M. 2005. Being goog or being known: an empirical examination of the dimension of the dimensions, antecedents, and consequences of organizational reputation. Academy of Management Journal 48 (6): 1033-1049.

Röhm, P., Köhn, A., Kuckertz, A., and Dehnen, H.S. 2018. A world of difference?: The impact of corporate venture capitalists' investment motivation on startup valuation. Journal of Business Economics 88 (3-4): 531-557.

Romain, A., van Pottelsberghe de Potterie, B. (eds.). 2004. The determinants of venture capital: Additional evidence. Frankfurt am Main: Dt. Bundesbank.

Romanelli, E., and Khessina, O.M. 2005. Regional Industrial Identity: Cluster Configurations and Economic Development. Organization Science 16 (4): 344-358.

Rosenthal, S.S., and Strange, W.C. 2003. Geography, Industrial Organization, and Agglomeration. The Review of Economics and Statistics 85 (2): 377-393.

Rossi, M., Festa, G., Solima, L., and Popa, S. 2017. Financing knowledge-intensive enterprises: Evidence from CVCs in the US. The Journal of Technology Transfer 42 (2): 338-353.

Rungi, M., Saks, E., \& Tuisk, K. (2016). Financial and strategic impact of VCs on start-up development: Silicon valley decacorns vs. Northern-European experience. In 2016 IEEE International Conference on Industrial Engineering and Engineering Management (IEEM), 452-456.

Safari, A. 2013. Worldwide Venture Capital and Patent Creation: Dissertation thesis.

Salamzadeh, A., and Hiroko, K.K. 2015. Startup companies: life cycle and challenges. SSRN Electronic Journal.

Saxenian, A. 1994. Regional advantage: Culture and competition in Silicon Valley and Route 128. Cambridge, Mass. [u.a.]: Harvard Univ. Press.

Schlichte, F., Junge, S., and Mammen, J. 2019. Being at the right place at the right time: Does the timing within technology waves determine new venture success? Journal of Business Economics 31 (1): 305.

Seppä, T.J., and Laamanen, T. 2001. Valuation of venture capital investments: empirical evidence. $R \& D$ Management 31 (2): 215-230.

Shapiro, C. 1983. Premiums for high quality products as returns to reputations. The Quarterly Journal of Economics 98 (4): 659-679. 
Simon, J.P. 2016. How to Catch a Unicorn: An exploration of the universe of tech companies with high market capitalisation. Luxembourg: Publications Office.

Solomon, G. 2015. To Burn or Not to Burn-Going Long. https://goinglongblog.com/to-burn-or-not-toburn/. Accessed 14 Mar 2017.

Stayton, J., and Mangematin, V. 2018. Seed accelerators and the speed of new venture creation. The Journal of Technology Transfer 15 (2): 1163-1187.

Sternberg, R., and Litzenberger, T. 2004. Regional clusters in Germany-their geography and their relevance for entrepreneurial activities. European Planning Studies 12 (6): 767-791.

Tiwari, R., Anjum, B., Chand, K., and Pathak, R. 2019. Sustainability of Inorganic Growth in Online Retail by Snapdeal: A Case Study. International Journal of Management Studies VI (1(1)): 12.

Tykvová, T. 2018. Venture capital and private equity financing: An overview of recent literature and an agenda for future research. Journal of Business Economics 88 (3-4): 325-362.

Ubeda, F., Ortiz-de-Urbina-Criado, M., and Mora-Valentín, E.-M. 2019. Do firms located in science and technology parks enhance innovation performance?: The effect of absorptive capacity. The Journal of Technology Transfer 44 (1): 21-48.

Vardi, M.Y. 2016. Are we headed toward another global tech bust? Communications of the ACM 59 (4): 5.

Vogel, R., Puhan, T.X., Shehu, E., Kliger, D., and Beese, H. 2014. Funding decisions and entrepreneurial team diversity: A field study. Journal of Economic Behavior and Organization 107: 595-613.

Wadhwa, A., and Phelps, C. 2009. An option to partner: a dyadic analysis of CVC relationships. Academy of Management Proceedings 2009 (1): 1-6.

Wang, Y., Pan, X., Ning, L., Li, J., and Chen, J. 2015. Technology exchange patterns in China: an analysis of regional data. The Journal of Technology Transfer 40 (2): 252-272.

Werth, J.C., and Boeert, P. 2013. Co-investment networks of business angels and the performance of their start-up investments. International Journal of Entrepreneurial Venturing 5 (3): 240-256.

Wright, M., Lockett, A., Pruthi, S., Manigart, S., Sapienza, H., Desbrieres, P., and Hommel, U. 2004. Venture Capital Investors, Capital Markets, Valuation and Information: US, Europe and Asia. Journal of International Entrepreneurship 2 (4): 305-326.

Wright, M., Pruthi, S., and Lockett, A. 2005. International venture capital research: From cross-country comparisons to crossing borders. International Journal of Management Reviews 7 (3): 135-165.

Yamawaki, H. 2002. The evolution and structure of industrial clusters in Japan. Small Business Economics 18: 121-140.

Zhang, J. 2009. The performance of university spin-offs: an exploratory analysis using venture capital data. The Journal of Technology Transfer 34 (3): 255-285.

Zhou, Y., and Xin, T. 2003. An innovative region in China: interaction between multinational corporations and local firms in a high-tech cluster in Beijing. Economic Geography 79 (2): 129-152.

Zimmerman, J.L. 2016. Private equity, the rise of unicorns, and the reincarnation of control-based accounting. Journal of Applied Corporate Finance 28 (3): 56-67.

Zörgiebel, S. 2016a. The Rise of the Unicorns-How Media Affects Start-up Valuations. Frankfurt: Goethe University.

Zörgiebel, S. 2016b. Valuation of IPOs with Negative Earnings. Frankfurt: Goethe University.

Zou, H., Chen, X., and Ghauri, P. 2010. Antecedents and consequences of new venture growth strategy: An empirical study in China. Asia Pacific Journal of Management 27 (3): 393-421.

Publisher's Note Springer Nature remains neutral with regard to jurisdictional claims in published maps and institutional affiliations. 